\author{
Review Article
}

\title{
Product Distribution of Chemical Product Using Catalytic Depolymerization of Lignin
}

\author{
D. Damayanti, Yeni Ria Wulandari, Ho-Shing Wu* \\ Department of Chemical Engineering and Materials Science, Yuan Ze University, \\ Taoyuan, 32003, Taiwan.
}

Received: 18th February 2020; Revised: 21 st May 2020; Accepted: 22 nd May 2020;

Available online: 30th July 2020; Published regularly: August 2020

\begin{abstract}
Lignin depolymerization is a very promising process which can generate value-added products from lignin raw materials. The main objective of lignin depolymerization is to convert the complex molecules of lignin into small molecules. Nevertheless, lignin is natural polymer which the molecules of lignin are extremely complicated due to their natural variability, and it will be a big challenge to depolymerize lignin, particularly high water yield. The various technology and methods are developed to depolymerize lignin into biofuels or bio chemical products including acid/base/metallic catalyzed lignin depolymerization, pyrolysis of lignin, hydroprocessing, and gasification. The distribution and yield of chemical products depend on the reaction operation condition, type of lignin and kind of catalyst. The reactor type, product distributions and specific chemicals (benzene, toluene, xylene, terephthalic acid) production of lignin depolymerization are intensive discussed in this review. Copyright (C) 2020 BCREC Group. All rights reserved
\end{abstract}

Keywords: Depolymerization; Catalyst; Lignin; Reactor; Product distribution; Chemical catalysis

How to Cite: Damayanti, D., Wulandari, Y.R., Wu, H.-S. (2020). Product Distribution of Chemical Product Using Catalytic Depolymerization of Lignin. Bulletin of Chemical Reaction Engineering \& Catalysis, 15(2), 432-453 (doi:10.9767/bcrec.15.2.7249.432-453)

Permalink/DOI: https://doi.org/10.9767/bcrec.15.2.7249.432-453

\section{Introduction}

Biopolymers already enhanced environmental problem than synthetic polymer, due to the climate change. Lignin is one of the essential components in biomass, and it can be converted into value added chemical. The second abundant of biomass in this planet is lignin, which is not a polysaccharide. Lignin contributes for strength of cell walls [1]. Furthermore, lignin can be taken a place of renewable source for energy, chemicals and materials [2]. The lignin has high content of aromatic subunits. The

* Corresponding Author.

Email: cehswu@saturn.yzu.edu.tw (H.-S. Wu);

Tel.: +886-3-4638800 (ext.2564);

Fax: +886-3-4631181; structure of lignin provides an energy density up to $30 \%$ higher than that of cellulosic polymers. Therefore, it makes lignin to be one of the few natural sources of aromatic molecules [3]. The structures of lignin are among hemicelluloses and cellulose micro-fibrils to create the mechanical backbone of vascular plants [4]. There is various type of lignocelluloses, which contain the different polymers. In hardwood stem, the xylem normally contains $40-55 \%$ of cellulose, $24-40 \%$ of hemicellulose and $18-25 \%$ of lignin, whereas the softwood stem contains $45-50 \%$ of cellulose, $25-35 \%$ of hemicellulose and $25-35 \%$ of lignin [5]. The total production kraft pulp worldwide approximately is up to 130 million tons. Furthermore, the production of lignin was estimated 70 million tons, which is available for utilization and valorization [6]. 
Furthermore, lignin will be a serious problem for pulp and paper industries [6-8]. The range of global production technical lignin approximately $1.65 \mathrm{Mt} / \mathrm{y}$ (except bioenergy production) which the lead of lignin production comes from lignosulfonates up to $80 \%$ of the market, and the major applications are surfactants, bonding agents for palletization, dispersants in ceramics and concrete admixtures [2].

Even though lignin is promising as a renewable source for value added product. Lignin have a huge issue for depolymerization process furthermore the wide range of various interunit linkages and the linkages of lignin for instance, low selectivity to get desired the product, separation, purification and char formation [9]. They will be affected on the limitation for scaling-up implementation of lignin goods as raw material to obtain valuable chemicals. In general, the products of lignin depolymerization are mainly solid char, liquid oil and gases, which compositions are different by using different depolymerization methods, such as: catalytic reaction, thermal pyrolysis, hydroprocessing, and gasification. It is rarely discussed or reviewed the contents of solid char, liquid oil, and gases are obtained by using the different depolymerizations. The phenolic compound was mainly chemicals in the liquid oil, but they are complicate and low percentage or cost. Furthermore, the production of specific high-value chemicals directly obtained from lignin depolymerization and the prevention of water production because of high oxide content in lignin are key issues. Hence, this review paper focuses on the three topics as follows: (i) to take a place from lignin transformation process for the low chain carbon production of biofuels that currently based on petroleum oil in the future bio refineries; (ii) to show the product distribution for various method of depolymerization lignin and distribution of lignin products for instance, acid/base catalyzed, metallic, hydroprocessing, pyrolysis, and gasification, and (iii) to discuss the specific of distribution product of lignin with different type and operation condition of lignin, particularly water content, benzene, toluene, and xylene (BTX), and terephthalic acid (TPA).

\section{Properties of Lignin}

One of the major components natural lignocellulosic of cell wall and the second most abundant plant polymers in our earth is lignin [10]. The source of lignin can be classified as native and synthetic lignin. Native lignin can be found in nature, and always exists as part of lignocel- lulose. The lignocellulose biomass is split up into aqueous sugar solution containing sugar monomers for instance glucan or xylan by the decomposition of cellulose and hemicellulose, and solid lignin after saccharification process. Especially, a significant amount of waste lignin is likely to by produced as by-product once biobutanol production process from waste wood [11]. Lignin can be classified based on the type of preparation methods, isolated lignin fragments can be divided into Klason lignin, milled wood lignin, enzymatic hydrolysis lignin, enzymatic/mild acidolysis lignin, acid lignin, alkali lignin, Kraft lignin, organosolv lignin, and lignosulfonate. The different fragments of lignin depend on the corresponding molecular weights, $\beta-\mathrm{O}-4$ linkage contents, as well as ratio of syringylpropane (S) to guaiacylpropane (G) [12]. The most common linkages in the polymerization process are $\beta$-O-4-aryl ether bonds. Moreover, the other important linkages include $\beta$-5-phenylcoumaran, 5-5-biphenyl, 4O-5-diaryl ether, $\beta$-1-(1,2-diarylpropane), $\beta$-O4 -aryl ether, and $\beta-\beta$-resinol linkages [13].

Lignin was described by isolation process in 1956 [14]. Lignin is able to isolate from the lignocellulosic raw materials by a variety of methods with different mechanical and chemical processes. The isolated method of lignin can be divided into two major pathways. The first group is to remove cellulose and hemicelluloses by solubilization and then, remove insoluble residue of lignin, and the second group involves the dissolution and removal of lignin, leaving cellulose and hemicelluloses as insoluble residues, followed by the recovery of lignin from the solution [15]. For first invention of isolation of lignin, lignin was extracted with dioxane water (96:4) from spruce wood for 6 weeks. The monolignols of lignin was found as precursors, such as: pcoumaryl, coniferyl, and sinapyl alcohols. They are hydroxycinnamic alcohols containing an aromatic ring [14]. Furthermore, the main source of synthetic lignin from industries is kraft lignin, and there are several other types of lignin sources like hydrolysis lignin, organosolv lignin, and pyrolytic lignin. Synthetic lignin from the industrial by-product can be directly used as feedstocks for another chemicals production. For instance, aliphatic and aromatic hydroxyl groups are the main feedstocks. Moreover, it also can be used as polyols for producing the polyurethane and replace $30 \%$ of petroleum-based polyols during the polyurethane production [5].

The production process of kraft lignin is started from wood-pulp, and then, the wood pulp added in $\mathrm{Na}_{2} \mathrm{~S} / \mathrm{NaOH}$ solution, which is 
called white liquor. The temperature range of kraft lignin production is $155-175{ }^{\circ} \mathrm{C}$ for several hours. The lignin dissolved is $90-95 \%$ during the reaction. In addition, lignoBoost is a well-proven technology for commercial-scale kraft lignin recovery. This process enables high-purity lignin production with rather low ash and carbohydrate contents [16]. On the other hand, the organosolv lignin is potential source of lignin and able to be dissolved in the organic solvent under certain condition. The advantages of organosolv process is their ability to produce high-purity lignin from biomass and sulphuric-free and less modification which favor to the downstream process during the production [5], but the yield of lignin is low in this process. In addition, hydrolytic lignin is a residue from bioethanol production. Cellulose in the lignocellulose is fermented to become bioethanol by various enzymes. Whereas, the linkage of lignin is extremely complex and hard so that lignin can't react with the enzyme. Therefore, the residue from bioethanol production become hydrolysis lignin. The production of hydrolysis lignin can be used for sorbents and resin etc. [17].
Lignin can be classified into several categories for instance, Type- $\mathrm{G}$ (softwood lignin), Type-G-S (hardwood lignin) and Type-H-G-S (grass lignin). The symbol of $\mathrm{G}, \mathrm{S}$, and $\mathrm{H}$ are represented as guaiacylpropane, syringylpropane, and phydroxyphenylpropane, respectively. Despite that, the structure of lignin matrix has different linkages (aryl- or alkyl-ether, ester and $\mathrm{C}-\mathrm{C}$ ) with various functional groups $\left(-\mathrm{OH},-\mathrm{OCH}_{3}, \mathrm{C}=\mathrm{O},-\mathrm{C}-\mathrm{OH}\right.$, propyl moiety) resulting in extremely convoluted lignin structures [18]. Furthermore, natural polymers, such as lignin linkages, are very complicated due to their natural variability. Lignin is not yet able to be isolated in its unaltered state so that the structure of photo - lignin is still relatively unknown [19].

In general, the structure of lignin is a threedimensional amorphous polymer consisting of methoxylated phenylpropane. The total of lignin compound and molecular weight will be different and it depends on kind of plant, with lignin abundance generally decreasing in the order of softwoods (27-33 wt\%) > hardwoods (18$25 \mathrm{wt} \%)>$ grasses $(17-24 \%)[13,20]$. The biosynthesis of lignin is thought to involve the

Table 1. Composition and configuration of cellulose, hemicellulose and lignin in the cell walls of plants.

\begin{tabular}{|c|c|c|c|c|}
\hline & Cellulose & Hemicellulose & Lignin & Refs. \\
\hline Subgroups & $\begin{array}{l}\text { D-pyran glucose } \\
\text { units }\end{array}$ & $\begin{array}{l}\text { D-xylose, mannose, } \\
\text { L-arabinose,galactose, } \\
\text { glucuronic acid }\end{array}$ & $\begin{array}{l}\text { guaiacylpropane }(\mathrm{G}) \text {, } \\
\text { syringylpropane }(\mathrm{S}) \text {, phy- } \\
\text { droxyphenylpropane } \\
(\mathrm{H})\end{array}$ & {$[25,26]$} \\
\hline $\begin{array}{l}\text { Bonds within } \\
\text { subgroups }\end{array}$ & $\begin{array}{l}\beta \text {-1,4-glycosidic } \\
\text { bonds }\end{array}$ & $\begin{array}{l}\beta-1,4 \text {-glycosidic bonds } \\
\text { in main chains; } \beta \text { - } 1.2- \\
\beta-1.3-, \beta-1.6 \text {-glycosidic } \\
\text { bonds in side chains }\end{array}$ & $\begin{array}{l}\text { Various ether bonds and } \\
\text { carbon-carbon bond, } \\
\text { mainly } \beta-O-4 \text { ether bond }\end{array}$ & {$[25,26]$} \\
\hline Polymerization & 100 to 10000 & Less than 200 & 4,000 & {$[25,26]$} \\
\hline Polymer & $\beta$-glucan & $\begin{array}{l}\text { polyxylose, } \\
\text { galactoglucomannan } \\
\text { (Gal-Glu-Man), } \\
\text { glucomannan (Glu- } \\
\text { Man) }\end{array}$ & $\begin{array}{l}\text { G lignin, GS lignin, GSH } \\
\text { lignin }\end{array}$ & {$[25,26]$} \\
\hline $\begin{array}{l}\text { Component } \\
\text { mixture }\end{array}$ & $\begin{array}{l}\text { three-dimensional } \\
\text { linear molecular } \\
\text { composed of the } \\
\text { crystalline region } \\
\text { and the amor- } \\
\text { phous } \\
\text { region }\end{array}$ & $\begin{array}{l}\text { three-dimensional } \\
\text { Inhomogeneous molecu- } \\
\text { lar with a small crystal- } \\
\text { line region }\end{array}$ & $\begin{array}{l}\text { amorphous, inhomogene- } \\
\text { ous, nonlinear } \\
\text { three-dimensional } \\
\text { polymer }\end{array}$ & {$[25,26]$} \\
\hline $\begin{array}{l}\text { Bonds between } \\
\text { three compo- } \\
\text { nents }\end{array}$ & $\begin{array}{l}\text { without chemical } \\
\text { bond }\end{array}$ & $\begin{array}{l}\text { contains chemical bond } \\
\text { with lignin }\end{array}$ & $\begin{array}{l}\text { contain chemical bond } \\
\text { with hemicellulose }\end{array}$ & {$[25,26]$} \\
\hline
\end{tabular}


polymerization of three primary monomers: pcoumaryl, coniferyl, and sinapyl alcohols [21]. Furthermore, $\beta-\mathrm{O}-4$ linkage is the most dominant of linkage in lignin [21]. The total linkage of softwood lignin for $\beta$-O-4, $\alpha-0-4, \beta-5,5-5,4$ $0-5, \beta-1$, and $\beta-\beta$ are $50,2-8,9-12,10-11,4,7$, and $2 \%$ respectively [22]. The hardwood contains more $\beta$-O-4-linkages than softwood. There are various functional groups in the structure of lignin including methoxyl, phenolic hydroxyl, aliphatic hydroxyl, benzyl alcohol, noncyclic benzyl ether and carbonyl groups which result in reactivity of the lignin in various chemical reactions [13]. The most frequent coupling linkages in the polymerization process are $\beta$-O-4aryl ether bonds. The other major linkages include $\beta$-5-phenylcoumaran, 5-5-biphenyl, 4-O5 -diaryl ether, $\beta$-1-(1,2-diarylpropane), $\beta$-O-4aryl ether, and $\beta-\beta$-resinol linkages [13]. The energy content of lignin has been studied by White and Plasket 1981 with the total energy content approximately $25.5 \mathrm{MJ} / \mathrm{kg}$, which is considerably higher than that of cellulose [23].

The phase transition temperature of lignin with the temperature range number of melting points is about $90-193^{\circ} \mathrm{C}$. The glass transition temperature of cellulose is up to $-27^{\circ} \mathrm{C}$ and the temperature differences is between 240 and $244^{\circ} \mathrm{C}$. On the other hand, the melting point of hemicellulose is dramatically dependent of the various of plant biomass, and not more than $167-181{ }^{\circ} \mathrm{C}$ [24]. Table 1 lists the composition and configuration of cellulose, hemicellulose and lignin in the cell walls of plants. The chemical linking between hemicellulose and cellulose is lignin which contains a small amount of carbohydrates besides that the chemical linking between hemicellulose and lignin mostly indicated to the chemical linking between galactose and arabitose residues on the side chains of hemicellulose molecules and lignin, and carbohydrates [25].

The type of reaction of lignin are separated into two main forms for example, nucleophilic reactions and electrophilic reactions. The linking unit of chemical reaction occurs on the side chain. It can conduct the nucleophilic reactions with lignin in alkaline media which reagents are led on $\mathrm{HO}^{-}, \mathrm{HS}$, and $\mathrm{S}^{2-}$ nucleophilic to break the primary chain with fragmentation and partial dissolution of macromolecule lignin. Furthermore, in neutral medium, the reaction with nucleophile $\mathrm{HSO}_{3}$ or $\mathrm{SO}_{3}{ }^{2-}$ leads to split the other chain, which produces $\mathrm{SO}_{3}{ }^{2-}$ groups in the depolymerization of lignin fragments. On the other hand, the acid media mostly related to fragmentation of acid sulfite pulping process. $\mathrm{SO}_{2}$ solution is taken as an affinity reagent, leading to the breakage of phenol-type and nonphenolic $\beta$-aryl ether linking chain, sulfonation of $\beta$-carbon, and to increase lignin hydrophilicity [27]. The density of lignin is approximated between 1.35 and 1.50 measured using water at $20{ }^{\circ} \mathrm{C}$. Furthermore, the relative density of sulfuric acid lignin isolated from pine is 1.45 and 1.44 by using benzene and the density of dioxane lignin approximately is 1.33 and 1.39 measured by using water and dioxane. The different type reparation of lignin has different relative densities, e.g. the relative density of pine glycol lignin is 1.36 , but it is 1.35 for pine hydrochloride lignin [28].

\section{Method to Depolymerization Lignin}

Lignin degradation can be influenced by thermochemical method, kind of solvents, chemical addictive and catalysts. The technologies of degrading lignin are pyrolysis, hydroprocessing, acid/based-catalyzed depolymerization, oxidation, etc. The products of pyrolysis

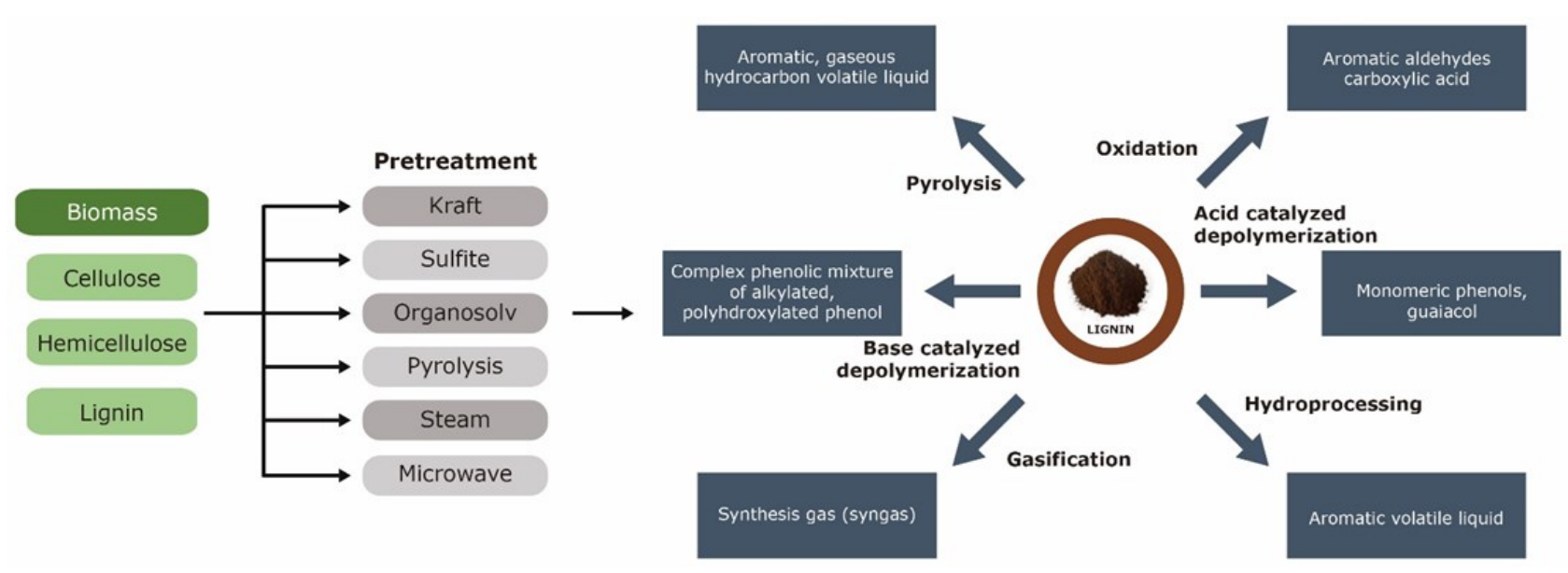

Figure 1. Scheme of product distribution in depolymerization of lignin [13,32]. 
are mainly solid char, liquid oil and gases. The yield percentage of product distribution depends on temperature and heating rate [29]. Figure 1 illustrates the scheme of product distribution in depolymerization of lignin. For depolymerization of lignin using a base catalytic reaction further by hydroprocessing, the major product is $\mathrm{C}_{7}-\mathrm{C}_{10}$ alkylbenzenes. The non - reactive solvent can be used in the hydrotreatment process in order that the amount of heat released within a catalyst bed is reduced due to a lower concentration of oxygen atoms in the combined feed corresponding to the bio-origin feed and the solvent [30]. The catalytic reactivity of biomass degradation was studied firstly by means of thermogravimetric analyzer (TGA), and then obtained the kinetic parameters and activation energies of biomass degradation [7,31].

Lignin depolymerization is the most potential method which can generate value-added products from lignin raw materials to convert the complex lignin compound into small molecules for fuels and basic chemicals or oligomers for further application [19]. Furthermore, there are several technologies to depolymerization of lignin by catalytic/depolymerization, such as: pyrolysis, cracking, hydrolysis, dehydroxygenation, reduction and oxidation processes, to produce various aromatic value-added monomeric unit or biofuels. Moreover, the biological methods have also been applied for the degradation of lignin, such as: (1) enzymatic oxidation. or (2) microbial conversion by microbes, bacteria, fungi, and termites capable of decomposing biomass to perform their metabolic functions [33]. Besides that, fast pyrolysis of lignocellulose is a thermochemical method to convert dry biomass to liquid, solid and gas products. In general, the fast pyrolysis is carried out with the temperature reaction $500{ }^{\circ} \mathrm{C}$ at atmospheric pressure with a residence time very quickly and the products distribution depend with reaction temperature, heating rate and lignin feedstock's compound. The yield of bio-oil from pyrolysis of lignocellulose approximately $75 \%$ and the total carbon, hydrogen and oxygen by elemental analysis were approximated 66\%, 6\% and $27 \%$, respectively [13].

In general, lignin depolymerization occur in an aqueous phase, organic phase or dry form. Whereas, the hydrogenolysis of natural lignin in the non-fractionated biomass, depolymerization of the isolated lignins results in a complex mixture of aromatic compounds in which the individual mass fraction of each compound barely exceeds few percent [13]. Mullen and Boateng studied for different source of lignin, such as: Asian, Lignol, and Bagasse lignin, which pyrolytic temperature was up to $650^{\circ} \mathrm{C}$ by a analytical method of pyrolysis (GC-MS). The average yield of products was $\sim 18 \%$ of noncondensable gases, $\sim 15 \%$ of char and $\sim 65 \%$ of condensable gases. The yield sequence of liquid products was phenol $<$ cresol $<$ guaiacol $<4$ methyl guaiacol < syringol. Furthermore, the percentage of abundance gases were $\mathrm{CO}_{2}(9 \%)$, $\mathrm{H}_{2} \mathrm{O}, \mathrm{CO}(5 \%), \mathrm{CH}_{4}(1.4 \%), \mathrm{CH}_{3} \mathrm{OH}$ and smaller amounts of higher hydrocarbons [34,35].

\subsection{Base-catalyzed Lignin Depolymerization}

In general, base-catalyzed lignin depolymerizations were carried out at temperature above $300{ }^{\circ} \mathrm{C}$ and a high pressure, which catechol, syringol, and derivatives were identified to be the most abundant components [36]. Miller et al reported alkali depolymerization of lignin using water as solvent. They found that the most important factor leading lignin depolymerization was base concentration. Therefore, they observed that molar excess of a strong base gave better results on lignin depolymerization [37]. Some literatures had been studied about the product of lignin depolymerization, such as: a complex phenolic mixture of alkylated and polyhydroxylated phenol compounds, as well as volatile components and char [32].

The base catalysts are cheap and commercially available bases, such as: $\mathrm{LiOH}, \mathrm{NaOH}$, and $\mathrm{KOH}$ [32]. More specifically depolymerization of lignin and the hydrothermal reaction are conducted in the presence of water at an alkaline solution $(\mathrm{pH}>8)$ and reaction temperature of $200-300{ }^{\circ} \mathrm{C}$ with a noble metal catalyst on carbon support as reported by Stephan et al. [38]. Chen and Koch studied the reaction of lignin with a hydrogenation catalyst under a hydrogen atmosphere to form a mixture, which was conducted in the lignin hydrolysis and aromatic hydrogenation at pressure of $3.4-14 \mathrm{MPa}$ and temperature of $325-450{ }^{\circ} \mathrm{C}$. Its products included water and an intermediate product (naphthenes and cyclohexane alcohols). The intermediate product was reacted with a deoxygenation and a dehydrogenation catalyst to generate a product stream comprising aromatic and phenolic compounds. The depolymerization process of the lignin with hydrogenation catalyst forms a mixture at $\mathrm{pH}$ greater than 6 [39].

Table 2 lists the effect of base-catalyzed reaction with major product, such as: guaiacol, catechol. The reaction temperature is operated at around $300^{\circ} \mathrm{C}$ and high pressure $(>34 \mathrm{~atm})$. Currently yield of major product is lower than $20 \%$. For example, Katahira et al. investigated 
Table 2. Base - catalyzed lignin depolymerization.

\begin{tabular}{|c|c|c|c|c|c|c|}
\hline \multirow{2}{*}{ Lignin } & \multirow{2}{*}{$\begin{array}{c}\text { Base } \\
\text { Catalyst }\end{array}$} & \multicolumn{2}{|c|}{$\begin{array}{l}\text { Reaction } \\
\text { Condition }\end{array}$} & \multirow{2}{*}{ Major Product } & \multirow{2}{*}{$\begin{array}{l}\text { Yield } \\
(\text { wt } \%)\end{array}$} & \multirow{2}{*}{ Ref. } \\
\hline & & $T\left({ }^{\circ} \mathrm{C}\right)$ & $P($ atm $)$ & & & \\
\hline Kraft lignin & $5 \mathrm{wt} \% \mathrm{NaOH}$ & $270-315$ & 128.3 & pyrocatechol & $0.5-0.9$ & {$[19]$} \\
\hline Organosolv lignin & 2 wt $\% \mathrm{NaOH}$ & 300 & 246.7 & $\begin{array}{l}\text { syringol, } \\
\text { hydroxyacetophenone, } \\
\text { guaiacol }\end{array}$ & $\begin{array}{l}4.1 \\
1.6 \\
1.1\end{array}$ & {$[19]$} \\
\hline $\begin{array}{l}\text { Organosov olive } \\
\text { tree pruning lig- } \\
\text { nin }\end{array}$ & $\begin{array}{l}4 \mathrm{wt} \% \\
\mathrm{NaOH}, \mathrm{KOH}, \\
\mathrm{Ca}(\mathrm{OH})_{2}, \mathrm{Li}- \\
\mathrm{OH}, \mathrm{K}_{2} \mathrm{CO}_{3}\end{array}$ & 300 & 888.2 & catechol & $0.1-2.4$ & [19] \\
\hline $\begin{array}{l}\text { Steam explosion } \\
\text { hemp lignin }\end{array}$ & $5 \mathrm{wt} \% \mathrm{NaOH}$ & $300-330$ & 34.5 & $\begin{array}{l}\text { guaiacol } \\
\text { gatechol } \\
\text { vanilin }\end{array}$ & $\begin{array}{l}0.9-2.8 \\
0.8-3.0 \\
0.5-0.8\end{array}$ & [19] \\
\hline $\begin{array}{l}\text { Steam explosion } \\
\text { softwood lignin }\end{array}$ & 5 wt $\% \mathrm{NaOH}$ & $300-330$ & 34.5 & $\begin{array}{l}\text { guaiacol } \\
\text { gatechol } \\
\text { vanilin }\end{array}$ & $\begin{array}{l}1.2-2.1 \\
0.1-3.2 \\
0.3-0.5\end{array}$ & {$[19]$} \\
\hline Organosolv lignin & $\mathrm{NaOH}$ & 300 & & monomeric phenol & $5-20$ & {$[32]$} \\
\hline $\begin{array}{l}\text { Steam explosion } \\
\text { lignin }\end{array}$ & $\mathrm{NaOH}$ & $300-330$ & 88-129 & $\begin{array}{l}\text { monomers, dimers } \\
\text { and trimmers }\end{array}$ & 70 & {$[32]$} \\
\hline $\begin{array}{l}\text { Kraft lignin from } \\
\text { soft wood }\end{array}$ & $\mathrm{NaOH}$ & 315 & NA & $\begin{array}{l}\text { gas, small organic } \\
\text { compounds, aromatic } \\
\text { monomers }\end{array}$ & 19.1 & {$[32]$} \\
\hline $\mathrm{HCl}$ lignin & Alkaline & 250 & NA & monomeric phenol & $16-18$ & {$[32]$} \\
\hline Alcell lignin & $\begin{array}{l}\text { Various inor- } \\
\text { ganic bases }\end{array}$ & 290 & NA & monomeric phenol & NA & {$[32]$} \\
\hline $\begin{array}{l}\text { Poplar wood saw- } \\
\text { dust }\end{array}$ & $\mathrm{NaOH}$ & 180 & NA & $\begin{array}{l}\text { low molecular phenol } \\
\text { compound }\end{array}$ & $21.8-53.2$ & {$[32]$} \\
\hline $\begin{array}{l}\text { Deacetylated corn } \\
\text { stover/disk re- } \\
\text { fined/EH residue } \\
(\mathrm{DDR}-\mathrm{EH})\end{array}$ & $2 \% \mathrm{NaOH}$ & 300 & NA & $\begin{array}{l}\text { phenol benzenediols } \\
\text { acetophenone } \\
\text { non- aromatic ketones }\end{array}$ & & {$[40]$} \\
\hline $\begin{array}{l}\text { Acetosolv pulping } \\
\text { lignin }\end{array}$ & 4 wt $\% \mathrm{NaOH}$ & 300 & 88.8 & $\begin{array}{l}\text { 4-methylcatechol } \\
\text { catechol } \\
\text { phenol }\end{array}$ & $\begin{array}{l}5.72 \pm 0.02 \\
6.25 \pm 1.20 \\
1.04 \pm 0.12\end{array}$ & [37] \\
\hline $\begin{array}{l}\text { Formosolv pulping } \\
\text { lignin }\end{array}$ & $4 \mathrm{wt} \% \mathrm{NaOH}$ & 300 & 88.8 & $\begin{array}{l}\text { catechol } \\
\text { 4-methylcatechol } \\
\text { 3-methylcatechol } \\
\text { phenol }\end{array}$ & $\begin{array}{l}11.8 \pm 1.68 \\
7.00 \pm 0.73 \\
4.40 \pm 0.24 \\
1.34 \pm 0.66\end{array}$ & {$[37]$} \\
\hline $\begin{array}{l}\text { Acetosolv / formo- } \\
\text { solv pulping lignin }\end{array}$ & 4 wt $\% \mathrm{NaOH}$ & 300 & 88.8 & $\begin{array}{l}\text { catechol } \\
\text { 4-methylcatechol } \\
\text { 3-methylcatechol } \\
\text { phenol }\end{array}$ & $\begin{array}{l}7.80 \pm 1.24 \\
6.21 \pm 0.91 \\
3.76 \pm 1.01 \\
0.96 \pm 0.17\end{array}$ & {$[37]$} \\
\hline
\end{tabular}

NA: Data Not Available. 
the depolymerization of lignin using base catalyst and $\mathrm{NaOH}(2-4 \mathrm{wt} \%)$ at $270-330{ }^{\circ} \mathrm{C}$. The base-catalytic depolymerization products from deacetylated corn stover / twin screw Refined / EH residue (DTSR-EH) have higher contents of non-aromatic ketones then but the products from deacetylated corn stover/disk refined/EH residue (DDR-EH) have the high content of residual carbohydrates. The relative abundance of lignin - derived products was decreased to zero at $330^{\circ} \mathrm{C}$ in $2 \% \mathrm{NaOH}$ and at $300-330{ }^{\circ} \mathrm{C}$ in $4 \% \mathrm{NaOH}$ as used kraft lignin, the most product for kraft lignin is non-aromatic ketones [40]. Erdocia et al. presented the yield of catechol was larger than $6 \%$ [37].

\subsection{Acid-catalyzed Lignin Depolymerizations}

The first acid-catalyzed lignin hydrolysis reaction was reported in 1924 [41], when Hägglund and Björkman distilled lignin with $12 \%$ hydrochloric acid to obtain thiobarbituric acid, phloroglucinol, and barbituric acid. Recently, different types of mineral acids, Lewis acids, zeolites, acidic ionic liquids, as well as organic acids have been tested for hydrolysis of lignin and the related model compounds [32]. Acid catalyst, commonly used for dealkylation of aromatics, is one of the several options for depolymerizing lignin [42]. The choice of the solvent plays an important role in determining the ability of a Lewis acidic salts to depolymerize lignin. Therefore, Güvenatam et al. studied about performance of metal acetate, chlorides or triflates was very poor, when lignin upgrading was carried out in supercritical water. The reactions with alcohol solvents, particularly in ethanol, lead to a much deeper lignin depolymerization. The addition of small amounts of water to the organic solvent can improve all the performance with significance $[43,44]$.

The conversion of lignin with solid acid catalyst under inert atmosphere to value added aromatics was exceptionally obtained high yields of $60 \%$ and $95 \pm 10 \%$ mass balance [45]. The acid-catalyzed depolymerization also focused on the cleavage of $\beta$-O- 4 bond of the lignin, and the reaction was completed for 2 to $4 \mathrm{~h}$ of the reaction. Formic acid or other acids provided hydrogen sources in the hydrolysis with the purpose of forming $\mathrm{H}_{3} \mathrm{O}^{+}$on the $\beta-\mathrm{O}-4$ bond or the cationic aromatic rings. The function of co-catalysts was usually to increase the selec-

Table 3. Acid-catalyzed lignin depolymerization.

\begin{tabular}{|c|c|c|c|c|c|c|}
\hline \multirow[t]{2}{*}{ Lignin } & \multirow{2}{*}{$\begin{array}{c}\text { Acid Catalyst } \\
\text { Alcohol Aqueous } \\
\text { Solution }\end{array}$} & \multicolumn{2}{|c|}{$\begin{array}{l}\text { Reaction } \\
\text { Condition } \\
\end{array}$} & \multirow[t]{2}{*}{ Major Product } & \multirow{2}{*}{$\begin{array}{l}\text { Yield } \\
\text { (wt\%) }\end{array}$} & \multirow[t]{2}{*}{ Ref } \\
\hline & & $T\left({ }^{\circ} \mathrm{C}\right)$ & $P($ atm $)$ & & & \\
\hline Wheat straw lignin & $\begin{array}{l}10 \mathrm{wt} \% \text { formic acid } \\
77 \mathrm{wt} \% \text { ethanol }\end{array}$ & 360 & 246.7 & $\begin{array}{l}\text { methoxyphenols } \\
\text { catechols } \\
\text { phenol }\end{array}$ & $\begin{array}{l}1.3 \\
0.5 \\
0.3\end{array}$ & [19] \\
\hline Wheat straw lignin & $\begin{array}{l}10 \mathrm{wt} \% \text { formic acid } \\
77 \mathrm{wt} \% \text { ethanol }\end{array}$ & 380 & 246.7 & $\begin{array}{l}\text { methoxyphenols } \\
\text { catechols } \\
\text { phenol }\end{array}$ & $\begin{array}{l}2.0 \\
1.7 \\
1.5\end{array}$ & [19] \\
\hline Wheat straw lignin & $\begin{array}{l}10 \mathrm{wt} \% \text { formic acid } \\
81 \mathrm{wt} \% \text { ethanol }\end{array}$ & 380 & 246.7 & $\begin{array}{l}\text { methoxyphenols } \\
\text { catechols } \\
\text { phenol }\end{array}$ & $\begin{array}{l}2.9 \\
1.5 \\
2.0\end{array}$ & [19] \\
\hline Organosolv lignin & $\begin{array}{l}10 \text { wt } \% \text { catalyst } \mathrm{NiCl}_{2} \text {, } \\
\mathrm{FeCl}_{3}\end{array}$ & 305 & NA & $\begin{array}{l}\text { ether soluble prod- } \\
\text { uct }\end{array}$ & NA & {$[32]$} \\
\hline Alcell lignin & HZSM-5 & 500 & NA & $\begin{array}{l}\text { gasoline range } \\
\text { hydrocarbon }\end{array}$ & NA & {$[32]$} \\
\hline Dealkaline lignin & $\begin{array}{l}\text { HUSY, HZSM- } 5 \text {, } \\
\text { HMOR, Clay K10, etc. }\end{array}$ & 250 & NA & aromatic monomer & NA & {$[32]$} \\
\hline Bjorkman lignin & Mineral acid & NA & NA & $\begin{array}{l}\text { ether-soluble prod- } \\
\text { uct }\end{array}$ & NA & {$[32]$} \\
\hline Bjorkman lignin & $\mathrm{CF}_{3} \mathrm{SO}_{3} \mathrm{H}$ & NA & NA & destructed lignin & NA & {$[32]$} \\
\hline Wheat straw & $\mathrm{Ga}(\mathrm{OTf})_{3}$ & 160 & NA & $\begin{array}{l}\text { ethanol - soluble } \\
\text { products }\end{array}$ & NA & {$[32]$} \\
\hline Woody mass & Hydrochloric acid & 120 & NA & $\begin{array}{l}\text { aromatic mole- } \\
\text { cules }\end{array}$ & NA & {$[32]$} \\
\hline
\end{tabular}

NA: Data Not Available. 
tivity [19]. Roberts et al. studied about hydrolyzed benzyl phenyl ether in both sub- and supercritical water at $320{ }^{\circ} \mathrm{C}$, the conversion reached $96 \%$ after $30 \mathrm{~min}$, whereas at $270{ }^{\circ} \mathrm{C}$, the reaction time is needed for $240 \mathrm{~min}$ to obtain the conversion to reach $91 \%$. At the high temperatures, primary products can rapidly oligomerize to reduce the yields of phenolics. The hydrochloric acid gives satisfying results for guaiacol hydrolysis to catechol but there are some potential drawbacks (e.g. corrosion issues from low $\mathrm{pH}$, postreaction neutralization, reuse of catalyst) to using hydrochloric acid [46]. Table 3 lists that the effect of acid-catalyzed lignin depolymerization with major product. The reaction temperature and pressure are high, even higher than those using base-catalyzed reaction. The yield of small chemicals is lower than 3\%. Acid-catalyzed method was investigated at a higher temperature range in order to depolymerize lignin, $10 \mathrm{wt} \%$ of formic acid associated with $77 \mathrm{wt} \%$ of ethanol was employed at the reaction and the major products are methoxyphenols, catechols, phenols [47].

\subsection{Metallic-catalyzed Lignin Depolymeriza- tions}

Pepper et al. studied the influence of a few catalysts $\left(\mathrm{Ni}, \mathrm{Pd} / \mathrm{C}, \mathrm{Rh} / \mathrm{C}, \mathrm{Rh} / \mathrm{Al}_{2} \mathrm{O}_{3}, \mathrm{Ru} / \mathrm{C}\right.$, $\left.\mathrm{Ru} / \mathrm{Al}_{2} \mathrm{O}_{3}\right)$ on softwood lignin hydrogenation. The lignin was converted into the monomeric products 4-propylguaiacol and dihydroconiferyl alcohol under mild conditions (3.4 MPa, $468 \mathrm{~K}$ ) [20]. The nickel catalyst provided a high conversion of above $60 \%$ and a high selectivity of 75 to $95 \%$ to guaiacols. More importantly, the reaction temperature was decreased to $200{ }^{\circ} \mathrm{C}$ from around $380{ }^{\circ} \mathrm{C}$ [19]. Table 4 indices the metallic-catalyzed lignin depolymerization with major product. The conventional catalysts are studied also for reductive lignin conversion. Elliot published an early study in which a variety of commercial catalysts (Co-Mo, Ni-Mo, Ni-W, $\mathrm{Ni}, \mathrm{Co}, \mathrm{Pd}$, and $\mathrm{Cu}-\mathrm{CrO}$ ) was screened for phenol hydrogenation / hydrodeoxygenation activity; the sulfided Co-Mo catalyst provided the best results, giving the highest yield of benzene $(34 \%)$ at $673 \mathrm{~K}[20,48]$.

An iron(II) sulfide catalyst with a cocatalyst of at least one sulfide of copper, silver, tin, cobalt, chromium, nickel, zinc, or molybdenum (e.g. Fe-S-Cu-Zn in a ratio of 10:12:1:1) was used, and the high yields of monomeric phenols were in part caused by alkylation of the phenolic solvent during the process, but nonetheless a lignin derived phenol yield of $21 \%$ was obtained [20].

\subsection{Pyrolysis of Lignin}

Pyrolysis of lignin has received more interest in recent decades, moreover to the development of new technological concepts and processes for obtaining high yield of liquid products and developing new methods for catalytic upgrading of pyrolysis fluids, to improve their quality for use as fuels or source of chemicals. The new analytical techniques were also developed to help understand the mechanisms of formation, as well as the composition of the liquid products [50]. Pyrolysis is a thermal decomposition of the biomass (or lignin) in the absence of oxygen, with or without any catalyst usually at the temperature between 300 and $600{ }^{\circ} \mathrm{C}[29]$.

The degradation reactions during pyrolysis, such as: depolymerization, hydrolysis, oxidation, dehydration, and decarboxylation, leads to a complex composition of oils that provides the potential chemicals; however, the challenge is the economical separation of products for the chemicals and the liquid fuels markets [50]. The pyrolysis method is used for commercial production of a wide range of fuels, solvents, chemicals and other products from biomass feedstock. Pyrolysis processes may be conventional or fast pyrolysis, depending on the operating conditions that are used.

\subsubsection{Conventional pyrolysis}

Conventional pyrolysis consists of the slow, irreversible, thermal decomposition of the organic components in biomass [51]. Conventional slow pyrolysis has been applied for thousands of years and mainly used to produce charcoal. In slow wood pyrolysis, biomass is heated to $500{ }^{\circ} \mathrm{C}$. The vapor residence time varies from $5 \mathrm{~min}$ to $30 \mathrm{~min}$. Vapors do not escape as rapidly as they do in fast pyrolysis. Thus, components in the vapor phase continue to react with each other as the solid char and any liquid are being formed. The heating rate in conventional pyrolysis is typically much slower than that in fast pyrolysis. A feedstock can be held at constant temperature or slowly heated. Vapors can be continuously removed as they are formed. Vacuum pyrolysis at slow or fast heating rates is another variant [52]. Table 5 lists the pyrolysis method and their variants. Uçar and Karagöz studied the effect of temperature on the product distribution in the slow pyrolysis of pomegranate seeds in a fixedbed reactor [53]. They could obtain the high liquid content $(>50 \%)$ but the biooil content was not high. The solid residue was slightly 
Table 4. Metallic-catalyzed lignin depolymerization.

\begin{tabular}{|c|c|c|c|c|c|}
\hline \multirow{2}{*}{ Lignin } & \multirow{2}{*}{ Metallic Catalyst } & \multicolumn{2}{|c|}{ Reaction Condition } & \multirow{2}{*}{ Major Product } & \multirow{2}{*}{ Ref } \\
\hline & & $T\left({ }^{\circ} \mathrm{C}\right)$ & $P($ atm $)$ & & \\
\hline Lignin & $\mathrm{Cu}-\mathrm{CrO}$ & 260 & 217.1 & $\begin{array}{l}\text { methanol, } \\
\text { 4-n-propylcyclohexanol, } \\
4-n- \\
\text { propylcyclohexanediol, } \\
\text { glycol }\end{array}$ & {$[20]$} \\
\hline Dimeric species & $\mathrm{Fe}_{2} \mathrm{O}_{3}, \mathrm{Al}_{2} \mathrm{O}_{3}$ & 450 & 493.4 & $\begin{array}{l}\text { benzenes, monophenols, } \\
\text { dimers }\end{array}$ & {$[20]$} \\
\hline Organosolv lignin & $\mathrm{Co}-\mathrm{Mo}, \mathrm{Al}_{2} \mathrm{O}_{3}$ & $450-400$ & 69.0 & Insoluble residue & {$[20]$} \\
\hline Organocell lignin & $\mathrm{Fe}_{2} \mathrm{O}_{3}$ & 380 & 98.6 & oils & {$[20]$} \\
\hline $\begin{array}{l}\text { Depolymerized lig- } \\
\text { nin }\end{array}$ & $\mathrm{Co}-\mathrm{Mo}, \mathrm{Al}_{2} \mathrm{O}_{3}$ & $350-375$ & $98.6-148$ & $\begin{array}{l}\text { toluene, ethylbenzene, } \\
\text { xylene, Trimethylben- } \\
\text { zenes, alkylbenzenes }\end{array}$ & {$[20]$} \\
\hline Organocell lignin & $\mathrm{Ni}-\mathrm{Mo}, \mathrm{Al}_{2} \mathrm{O}_{3}$ & $400-375$ & $98.6-177.4$ & $\begin{array}{l}\text { phenol, cresols, al- } \\
\text { kylphenols } \\
\text { xylenols, guaiacol }\end{array}$ & {$[20]$} \\
\hline Organocell lignin & Ni-Mo, zeolite & 380 & 98.6 & oils & {$[20]$} \\
\hline $\begin{array}{l}\text { Organocell or Kraft } \\
\text { lignin }\end{array}$ & $\begin{array}{l}\text { Ni-Mo, } \mathrm{SiO}_{2}-\mathrm{Al}_{2} \mathrm{O}_{3} \text { or } \\
\text { zeolite }\end{array}$ & 400 & 98.6 & oils & {$[20]$} \\
\hline Kraft lignin & $\mathrm{NiCl}_{2}-\mathrm{ZSM}-5$ & 700 & & $\begin{array}{l}\text { heavy oil ( } 34.5 \mathrm{wt} \%) \text {, } \\
\text { light oil (11.5 wt\%) }\end{array}$ & [49] \\
\hline Kraft lignin & $\begin{array}{l}\text { (1) } \mathrm{Si}-\mathrm{Al} \text { catalyst/ } \\
\mathrm{H}_{2} \mathrm{O} / \text { butanol } \\
\text { (2) } \mathrm{ZrO}_{2}-\mathrm{Al}_{2} \mathrm{O}_{3}-\mathrm{FeO}_{\mathrm{x}}\end{array}$ & $\begin{array}{c}200-350 \\
300\end{array}$ & $10.8-226.9$ & phenols & {$[20]$} \\
\hline $\begin{array}{l}\text { Organosolv } \\
\text { switchgrass lignin }\end{array}$ & $\begin{array}{l}16 \mathrm{wt} \% \text { formic acid } \\
4 \mathrm{wt} \% \mathrm{Pt} / \mathrm{C} \\
80 \mathrm{wt} \% \text { ethanol }\end{array}$ & 350 & NA & $\begin{array}{l}\text { 4-propylguaiacol, 4- } \\
\text { Methylguaiacol }\end{array}$ & [19] \\
\hline $\begin{array}{l}\text { Acidic hydrolysis } \\
\text { spruce lignin }\end{array}$ & $\begin{array}{l}4.4 \mathrm{wt} \% \text { formic acid } \\
0.15 \mathrm{wt} \% \text { Pd catalyst } \\
0.94 \mathrm{wt} \% \text { Nafion } \\
\text { SAC- } 13\end{array}$ & 300 & NA & $\begin{array}{l}\text { guaiacol } \\
\text { pyrocatechol } \\
\text { resorcinol }\end{array}$ & [19] \\
\hline $\begin{array}{l}\text { Enzymatic hydroly- } \\
\text { sis spruce } \\
\text { lignin }\end{array}$ & $\begin{array}{l}4.4 \mathrm{wt} \% \text { formic acid } \\
0.15 \mathrm{Pd} \text { catalyst } \\
0.94 \mathrm{wt} \% \text { Nafion } \\
\text { SAC- } 13\end{array}$ & 300 & NA & $\begin{array}{l}\text { guaiacol } \\
\text { pyrocatechol } \\
\text { resorcinol }\end{array}$ & [19] \\
\hline Kraft spruce lignin & $\begin{array}{l}4.4 \mathrm{wt} \% \text { formic acid } \\
0.15 \mathrm{wt} \% \text { Pd catalyst } \\
0.94 \mathrm{wt} \% \text { Nafion } \\
\text { SAC- } 13\end{array}$ & 300 & NA & $\begin{array}{l}\text { guaiacol } \\
\text { pyrocatechol } \\
\text { resorcinol }\end{array}$ & [19] \\
\hline Lignosulfonate & $\begin{array}{l}\mathrm{Ni} / \mathrm{C}, \mathrm{NiLa} / \mathrm{C}, \\
\mathrm{NiPt} / \mathrm{C}, \mathrm{NiCu} / \mathrm{C}, \\
\mathrm{NiPd} / \mathrm{C} \text {, and } \mathrm{NiCe} / \mathrm{C}\end{array}$ & 200 & NA & guaiacol & [19] \\
\hline $\begin{array}{l}\text { Organosolv olive } \\
\text { tree pruning lignin }\end{array}$ & $\begin{array}{l}\mathrm{Ni}, \mathrm{Pd}, \mathrm{Pt} \text {, or Ru sup- } \\
\text { ported by mesoporous } \\
\text { Al-SBA-15 }\end{array}$ & 140 & NA & diethyl phthalate & [19] \\
\hline
\end{tabular}

NA: Data Not Available. 
changed when the reaction temperature was larger than $500{ }^{\circ} \mathrm{C}$.

\subsubsection{Fast pyrolysis}

Fast pyrolysis is a high-temperature process in which biomass is rapidly heated in the absence of oxygen [52]. Short residence time pyrolysis (fast, flash, rapid, ultra-pyrolysis) of biomass at moderate temperatures has generally been used to obtain high yield of liquid products. Fast pyrolysis is characterized by high heating rates and rapid quenching of the liquid products to terminate the secondary conversion of the products [54]. The liquid fraction is a complex mixture of water and organic chemicals [51]. The cleavage of $\mathrm{OH}$ functional group linked to aliphatic side chain, the breaking of alkyl side chain, aryl ether, and linkage between aromatic rings occur when temperature increases, forming a mixture of phenol, guaiacol, syringol, and catechols. Moreover, the aromatic ring cracking was occurred at above 500
${ }^{\circ} \mathrm{C}$ [19]. Fast pyrolysis uses much faster heating rates than traditional pyrolysis. Advanced processes are carefully controlled to give high liquid yields. four essential features of a fast pyrolysis process was used: (i) very high heating and heat transfer rates are used, which usually requires a finely ground biomass feed, (ii) a carefully controlled pyrolysis reaction temperature is used, often in the temperature range of $425-500{ }^{\circ} \mathrm{C}$, (iii) short vapor residence times are used (typically $<2$ s), and (iv) pyrolysis vapors and aerosols are rapidly cooled to give bio-oil [52]. In general, fast pyrolysis processes produce $60-75 \mathrm{wt} \%$ of liquid bio-oil, 15$25 \mathrm{wt} \%$ of solid char, and 10-20 wt\% of no condensable gases. Charon et al. reported that they obtained high percentage of liquid product but including high water content in a fluidized bed reactor [55] (Table 5).

Recently, the technology of pyrolysis has been developed due to its advantages of materials adaptability, product diversity, reaction

Table 5. Summary of product distribution of biomass pyrolysis for different reaction conditions.

\begin{tabular}{|c|c|c|c|c|c|c|c|c|c|}
\hline \multirow[b]{2}{*}{ Feedstock's } & \multirow[b]{2}{*}{$T\left({ }^{\circ} \mathrm{C}\right)$} & \multicolumn{3}{|c|}{ Product (\%) } & \multirow{2}{*}{$\begin{array}{l}\text { Unidentified }^{1 /} \\
\text { bio-oil } 2 / \text { water } \\
\text { content }^{3}(\%)\end{array}$} & \multirow[b]{2}{*}{ Reactor } & \multirow{2}{*}{$\begin{array}{c}\text { Inert } \\
\text { gas }\end{array}$} & \multirow{2}{*}{$\begin{array}{l}\text { Heating } \\
\text { ramp }\end{array}$} & \multirow[b]{2}{*}{ Ref. } \\
\hline & & Gas & Liquid & Solid & & & & & \\
\hline Solid lignin residue & 375 & 0.46 & 1.73 & 87.4 & 10.41 & pyroprobe & $\mathrm{N}_{2}$ & $150 \mathrm{~K} / \mathrm{min}$ & {$[57]$} \\
\hline Solid lignin residue & 440 & 5.39 & 2.67 & 80.6 & 11.41 & pyroprobe & $\mathrm{N}_{2}$ & $150 \mathrm{~K} / \mathrm{min}$ & [57] \\
\hline Solid lignin residue & 500 & 6 & 10.7 & 64.3 & 18.91 & pyroprobe & $\mathrm{N}_{2}$ & $150 \mathrm{~K} / \mathrm{min}$ & {$[57]$} \\
\hline $\begin{array}{l}\text { Ethanol organosolv } \\
\text { lignin }\end{array}$ & 375 & 0.04 & 0.38 & 87.2 & 12.41 & pyroprobe & $\mathrm{N}_{2}$ & $150 \mathrm{~K} / \mathrm{min}$ & [57] \\
\hline $\begin{array}{l}\text { Ethanol organosolv } \\
\text { lignin }\end{array}$ & 440 & 0.36 & 1.01 & 82.9 & 15.71 & pyroprobe & $\mathrm{N}_{2}$ & $150 \mathrm{~K} / \mathrm{min}$ & {$[57]$} \\
\hline $\begin{array}{l}\text { Ethanol organosolv } \\
\text { lignin }\end{array}$ & 500 & 0.75 & 4 & 81.9 & 13.31 & pyroprobe & $\mathrm{N}_{2}$ & $150 \mathrm{~K} / \mathrm{min}$ & {$[57]$} \\
\hline Alkaline lignin & 650 & 47.8 & 39.5 & 12.7 & NA & coil pyrolyzer & NA & NA & {$[58]$} \\
\hline Lignin B & 650 & 29.3 & 0.2 & 24 & 46.51 & $\begin{array}{l}\text { curie point } \\
\text { pyrolyzer }\end{array}$ & $\mathrm{He}$ & NA & {$[59]$} \\
\hline Hardwood & 470 & 12.3 & 38.8 & 15.1 & 30.43 & fluidized bed & $\mathrm{N}_{2}$ & NA & {$[55]$} \\
\hline Softwood & 470 & 9.5 & 44.1 & 25.8 & 30.03 & fluidized bed & $\mathrm{N}_{2}$ & NA & {$[55]$} \\
\hline Straw & 470 & 15.8 & 15.7 & 25.8 & 42.83 & fluidized bed & $\mathrm{N}_{2}$ & NA & {$[55]$} \\
\hline $\begin{array}{l}\text { Softwood Kraft Lig- } \\
\text { nin }\end{array}$ & NA & 21.4 & 36.1 & 42.5 & NA & microwave & NA & NA & {$[60]$} \\
\hline ALM Lignin & 500 & 5.7 & 19.8 & 40.9 & 11.42 & $\begin{array}{l}\text { instrument } \\
\text { pyroprobe }\end{array}$ & NA & NA & {$[61]$} \\
\hline $\begin{array}{l}\text { Softwood bark resi- } \\
\text { due }\end{array}$ & 500 & 27.4 & 45 & 27.4 & 132 & $\begin{array}{l}\text { continues and } \\
\text { batch reactor }\end{array}$ & NA & NA & {$[62]$} \\
\hline $\begin{array}{l}\text { Hardwood rich in } \\
\text { fibers }\end{array}$ & 500 & 19.9 & 53.9 & 26.2 & 132 & $\begin{array}{l}\text { continues and } \\
\text { batch reactor }\end{array}$ & NA & NA & {$[62]$} \\
\hline Pomegrate & 400 & 16.3 & 42.2 & 41.5 & 8.882 & fixed Bed & $\mathrm{N}_{2}$ & NA & {$[53]$} \\
\hline Pomegrate & 500 & 16.1 & 54 & 29.8 & 21.32 & fixed Bed & $\mathrm{N}_{2}$ & NA & {$[53]$} \\
\hline Pomegrate & 600 & 16.5 & 54.2 & 29.3 & 22.22 & fixed Bed & $\mathrm{N}_{2}$ & NA & {$[53]$} \\
\hline Pomegrate & 800 & 20.1 & 52.1 & 27.9 & 21.52 & fixed Bed & $\mathrm{N}_{2}$ & NA & {$[53]$} \\
\hline Kraft lignin & $627-967$ & $32-40$ & $17-2$ & $21-27$ & $15-20^{2}$ & microwave & NA & NA & {$[63]$} \\
\hline Read Oak & 500 & 11.6 & 61.1 & 13.2 & 14.11 & fluid bed & $\mathrm{N}_{2}$ & NA & [64] \\
\hline
\end{tabular}

NA: Data Not Available; ${ }^{1}$ Unidentified; ${ }^{2}$ Bio-oil; ${ }^{3}$ Water content 
rate and conversion yield [56]. The main reaction during pyrolysis process is the stage of dehydration process by then, the kinetically is controlled by an energy barrier for instance the water evaporation or water diffusion. The range of decomposition process of pyrolysis is $200-500{ }^{\circ} \mathrm{C}$ and the last stage of pyrolysis process is final char formation. In this stage, the poly-cyclic aromatic hydrocarbon $(\mathrm{PAH})$ is extremely dominant via radical mechanisms [7]. The earlier literature usually relates pyrolysis to carbonization, in which the initial product is a solid char [52]. In Table 5, if the pyrolysis of solid lignin residue was used the operation conditions by pyroprobe reactor presented by Cho et al. the solid residue will be $68-87 \%$ (unreacted lignin and solid polyaromatic products) because a high concentration of pyrolysis vapors form in the pyroprobe which induces further repolymerization or condensation. Moreover, the gas products distribution are carbon dioxide and carbon monoxide, with the percentage of gas products less than $6 \%$. On the other hand, ethanol organosolv lignin had

Table 6. Summary of water content from liquid product pyrolysis.

\begin{tabular}{|c|c|c|c|c|c|}
\hline Feedstock & Methods & $\mathrm{T}\left({ }^{\circ} \mathrm{C}\right)$ & Product & $\begin{array}{c}\text { Water } \\
\text { content } \\
(\%)\end{array}$ & Ref. \\
\hline Softwood Kraft lignin & $\begin{array}{l}\text { Microwave-pyrolysis } \\
\text { Karl Fischer }\end{array}$ & $\mathrm{NA}$ & Light bio-oil & 78 & {$[60]$} \\
\hline Softwood Kraft lignin & $\begin{array}{l}\text { Microwave-pyrolysis } \\
\text { Karl Fischer }\end{array}$ & NA & Heavy bio-oil & 14 & {$[60]$} \\
\hline Kraft lignin & $\begin{array}{l}\text { Microwave-pyrolysis } \\
\text { Karl Fischer }\end{array}$ & 627 & Aqueous phase & 91 & {$[63]$} \\
\hline Kraft lignin & $\begin{array}{l}\text { Microwave-pyrolysis } \\
\text { Karl Fischer }\end{array}$ & 707 & Aqueous phase & 76 & [63] \\
\hline Kraft lignin & $\begin{array}{l}\text { Microwave-pyrolysis } \\
\text { Karl Fischer }\end{array}$ & 792 & Aqueous phase & 90 & {$[63]$} \\
\hline Kraft lignin & $\begin{array}{l}\text { Microwave-pyrolysis } \\
\text { Karl Fischer }\end{array}$ & 877 & Aqueous phase & 78 & {$[63]$} \\
\hline Kraft lignin & $\begin{array}{l}\text { Microwave-pyrolysis } \\
\text { Karl Fischer }\end{array}$ & 967 & Aqueous phase & 73 & {$[63]$} \\
\hline Kraft lignin & $\begin{array}{l}\text { Microwave-pyrolysis } \\
\text { Karl Fischer }\end{array}$ & 627 & Oil Phase & 10 & {$[63]$} \\
\hline Kraft lignin & $\begin{array}{l}\text { Microwave-pyrolysis } \\
\text { Karl Fischer }\end{array}$ & 707 & Oil Phase & 21 & {$[63]$} \\
\hline Kraft lignin & $\begin{array}{l}\text { Microwave-pyrolysis } \\
\text { Karl Fischer }\end{array}$ & 792 & Oil Phase & 14 & [63] \\
\hline Kraft lignin & $\begin{array}{l}\text { Microwave-pyrolysis } \\
\text { Karl Fischer }\end{array}$ & 877 & Oil Phase & 14 & {$[63]$} \\
\hline Kraft lignin & $\begin{array}{l}\text { Microwave-pyrolysis } \\
\text { Karl Fischer }\end{array}$ & 967 & Oil Phase & 12 & {$[63]$} \\
\hline Red Oak & $\begin{array}{l}\text { Bed fluidization } \\
\text { Karl Fischer }\end{array}$ & NA & Bio-oil & 26.8 & {$[64]$} \\
\hline Forest residue-derived & Karl Fischer & NA & Bio-oil & 25.6 & [72] \\
\hline Pine-derived & Karl Fischer & NA & Bio-oil & 24.9 & [73] \\
\hline Air-dried switchgrass & $\begin{array}{l}\text { Schott TitroLine Karl } \\
\text { Fischer }\end{array}$ & NA & Crude bio-oil & 43.3 & [73] \\
\hline Air-dried switchgrass & $\begin{array}{l}\text { Schott TitroLine Karl } \\
\text { Fischer }\end{array}$ & NA & Aqueous phase & 92.2 & {$[73]$} \\
\hline Air-dried switchgrass & $\begin{array}{l}\text { Schott TitroLine Karl } \\
\text { Fischer }\end{array}$ & NA & Organic phase & 15.9 & {$[73]$} \\
\hline Rape straw & Karl-Fischer & 550 & Light phase & 52.2 & {$[74]$} \\
\hline Rape straw & Karl-Fischer & NA & Heavy phase & 13.1 & {$[74]$} \\
\hline Raw-Rice straw & Karl-Fischer & NA & Bio-oil & 49.4 & {$[75]$} \\
\hline Bamboo & Karl-Fischer & NA & Bio-oil & 40 & {$[76]$} \\
\hline
\end{tabular}

NA: Data Not Available. 
fewer - gas production than solid lignin residue at the same pyrolysis conditions. The amount of 12 to $30 \%$ of carbon was collected as liquid product [57].

Pilot scare process was used to determine product distribution [65-67]. Matos et al. indicated that the higher water content of aqueous extract had a negative effect for its application as fuel [65]. Lee studied the effect of products yield from biobutanol process derived lignin pyrolysis bench scale fixed bed and rotary kiln reactor with the flow rate $100 \mathrm{~g} / \mathrm{h}$ at $600{ }^{\circ} \mathrm{C}$. The yield of bio oil using fixed bed and rotary kiln are $33.9 \mathrm{wt} \%$ and $31.6 \mathrm{wt} \%$, respectively and water content in bio oil are $25.3 \mathrm{wt} \%$ and 10.0 $\mathrm{wt} \%$, respectively. The amount of gas and char for both reactors are 28.4 and $26.3 \mathrm{wt} \% ; 37.70$ and $42.1 \%$, respectively [11]. Moreover, Matos already studied the pilot - scaled fast pyrolysis conversion of eucalyptus wood fines into products which total sulfur from bio oil and aqueous extract were 85 and $76 \mathrm{mg} / \mathrm{kg}$, respectively, and total density were 122.6 and $1102 \mathrm{~kg} / \mathrm{m}^{3}$ at 20 ${ }^{\circ} \mathrm{C}$ [65]. The strong acidity of bio-oils makes them extremely unstable because of their complex compositions, which start boiling below $100{ }^{\circ} \mathrm{C}$ to stop at $250-280{ }^{\circ} \mathrm{C}$, leaving $35-$ $50 \mathrm{wt} \%$ as solid residues. Therefore, bio-oils can not be used in the instance of complete evaporation before combustion [68]. The pyrolysis of lignin is produced water formation and automatically from into two phases. Table 6 lists the summary of water content from liquid product pyrolysis. The water content was high in the product of lignin depolymerization. Farag et $a l$. had been investigation about the formation of water in pyrolysis process, the upper layer (light bio oil) is mostly water ( $78 \%$ determined by Karl-Fischer titration), while the bottom layer (heavy bio-oil) contains a lot of phenols and much less water (14\% determined by Karl Fischer titration) [60]. Water in liquid products affects the initial moisture in the feedstock because of the dehydration reactions happening during pyrolysis.

The presence of large amounts of oxygen content in biomass makes higher water content in product brown solid and lignin pyrolysis. The oxygen content reacts with hydrogen during the pyrolysis of biomass, thus making the production of water. However, increasing trend of water could be explained on several reasonable reactions between the organic chemicals, such as esterification of alcohols with acids, the production of acetals in aldehydes or ketones and alcohols, and polymerization of phenols with aldehyde hydrates, each of which could provide water [69].
The start of thermal decomposition for hemicellulose happens at lower temperatures than that for crystalline cellulose [52]. Bio-oil from lignocellulosic biomass pyrolysis includes more crucial water content (15-30\%) [68] than that from lignin pyrolysis $(8-15 \%)[32,70]$. The dehydration reactions happen significantly during the decomposition of cellulose and hemicellulose. They are two primary compounds in the lignocellulosic biomass [70] to produce anhydrocellulose and levoglucosan necessarily. Degradation of hemicellulose yields essentially acetic acid and furan derivatives. The water in liquid product is originated from both a dehydration reaction of organic compounds (mainly cellulose and hemicellulose) and free water (moisture) in the biomass [71].

\subsection{Hydroprocessing}

Hydroprocessing involves thermal reduction of the feed by hydrogen. It is one of the most popular and efficient strategies applied in deconstruction of lignin into components, such as: low depolymerized lignin, phenols, and other valuable chemicals, and upgrading of the small compounds to hydrocarbon fuels. The reaction types of hydroprocessing include hydrogenolysis, hydroalkylation, hydrodeoxygenation, hydrogenation, and integrated hydrogen-related reactions [32]. Mäki-Arvela and Murzin reviewed the hydrodeoxygenation (HDO) of biooils, lignin, and their model compounds towards industrial application [77]. Delledonne et al. studied about process for converting lignin to liquid hydrocarbons by hydrogenation. A lignin in the presence of at least one hydrogenolysis catalyst, selected from supported catalysts, such as: $\mathrm{M}^{1} / \mathrm{C}, \quad \mathrm{M}^{1} / \mathrm{Al}_{2} \mathrm{O}_{3}, \quad \mathrm{M}^{2} / \mathrm{SiO}_{2}$, $\mathrm{M}^{2} / \mathrm{Al}_{2} \mathrm{O}_{3}$ where, $\mathrm{M}^{1}$ is a metal selected from the group consisting of palladium, ruthenium, and platinum, and $\mathrm{M}^{2}$ is nickel, to obtain a depolymerized lignin at $250-350{ }^{\circ} \mathrm{C}$. Shimanskaya et al. reported the highest selectivity towards the oxygen free hydrocarbons $(96 \%)$ at the maximal conversion (68\%) of lignin- containing material was reached in the presence of $5 \% \mathrm{Pt} / \mathrm{MN}-270$ catalyst [78].

\subsection{Gasification}

Gasification represents a process that converts lignocellulosic materials into $\mathrm{CO}_{2}, \mathrm{CO}$, and $\mathrm{H}_{2}$ at the temperature between 700 and $1000{ }^{\circ} \mathrm{C}$. The mixtures of the gases are referred to as "syngas", which is the only useful product from the process [29]. Assuming a gasification process, the first step of the process is a thermochemical decomposition of the lignocellulosic 
compounds with production of char and volatiles. Further the gasification reactions were shown in Equations (1)-(4) [79].

$$
\begin{aligned}
& \mathrm{C}+\mathrm{H}_{2} \mathrm{O} \Leftrightarrow \mathrm{CO}+\mathrm{H}_{2} \\
& \mathrm{C}+\mathrm{CO}_{2} \Leftrightarrow 2 \mathrm{CO} \\
& \mathrm{CO}+\mathrm{H}_{2} \mathrm{O} \Leftrightarrow \mathrm{H}_{2}+\mathrm{CO}_{2} \\
& \mathrm{CH}_{4}+\mathrm{H}_{2} \mathrm{O} \Leftrightarrow \mathrm{CO}+3 \mathrm{H}_{2}
\end{aligned}
$$

The main gaseous products from biomass are:

$$
\begin{aligned}
& \text { Pyrolysis of biomass } \rightarrow \mathrm{H}_{2}+\mathrm{CO}_{2} \\
& +\mathrm{CO}+\text { hydrocarbon gases } \\
& \text { Catalytic steam reforming of biomass } \rightarrow \\
& \quad \mathrm{H}_{2}+\mathrm{CO}_{2}+\mathrm{CO} \\
& \text { Gasification of biomass } \rightarrow \mathrm{H}_{2}+\mathrm{CO}_{2} \\
& \quad+\mathrm{CO}+\mathrm{N}_{2}
\end{aligned}
$$

Heat to drive gasification reactions is generated in two ways: (i) indirect gasification, where heat is generated outside the gasifier and transferred into the gasifier, or (ii) direct gasification, where the heat is generated by exothermic combustion and partial combustion reactions inside the gasifier [29]. The gasification of biomass is a thermal treatment, which results in a high production of gaseous products and small quantities of char and ash [79] which is the purpose of process biomass gasification to synthesize gas production (syngas) and to obtain high-valued chemicals, such as gasoline, diesel fuel and jet fuels [67]. By comparison to traditional gasification which it consumed bunch of energy for biomass depolymerization, supercritical water (or hydrothermal) gasification is quite effective to save energy with no further requirement of biomass drying. Lignocellulose biomass compounds can break down into small molecules throughout supercritical water gasification (SCWG) to produce synthesis gas or syngas [80]. Syngas is produced by gasification process. The mixture product of gasification process has large amount of organic impurities called tar. In general, tar is determined as a complex mixture of condensable hydrocarbons, comprising a single ring to 5-ring aromatic compounds and other oxygen-containing organic molecules [81].

The larger $\mathrm{H}_{2}$ form in SCWG is related to the water excess that encourages both steam reforming and water gas shift reactions leading to a hydrogen-rich stream with poor $\mathrm{CO}$ content. The biomass has large water content up to $95 \%$ and before gasification process, it required to dry. Hence, it need more expense for pretreatment. On the other hand, SCWG technology took a part with highly wet biomass, and contributed with reducing the drying expense rather than the conventional gasification [82]. Cao studied regarding co-gasification of plastic wastes and soda lignin in supercritical water. The gasification process by different types of plastic showed that the sequence of polymer gasification efficiencies was $\mathrm{PE}>\mathrm{PC}>\mathrm{PP}>$ ABS. Besides that, the carbon gasification efficiency (CE) of PE was the highest (53.27\%), which was almost twice of that of ABS (29.81\%). Moreover, the addition of soda lignin improved the number of carbon gasification efficiency with plastics. The CE of PE, PP, PC and $\mathrm{ABS}$ were enhanced from $53.27 \%, 41.05 \%$, $43.70 \%$ and $29.81 \%$ to $70.85 \%, 63.01 \%, 60.25 \%$ and $36.73 \%$ respectively because of soda lignin addition which provided the alkali salts as well as a catalyst to promote the gasification [83].

Oxidative depolymerization of lignin is a valorization strategy that focuses on producing polyfunctional aromatic compounds. The oxidation products of lignin are mainly polyfunctional monomeric compounds, ranging from aromatic aldehydes to carboxylic acids, such as: vanillin, syringaldehyde, 4-hydroxybenzaldehyde, and muconic acid, which are alternative to fossil fuels derived chemicals [32].

\section{Specific Chemicals Converting from Lignin}

4.1 Highly Selective BTX by Catalytic Pyrolysis Process

The aromatics of benzene, toluene, and xylene (BTX) are the lowest molecular weight aromatic hydrocarbon. They used large scale chemical feedstock. BTX was obtained commercially by pyrolysis of coal, since World War II, the production of BTX has been intimately connected with the production of gasoline. BTX constitutes part of an important gasoline component is called reformate. Reformate is highly valued for gasoline because it has a very high octane rating $[84,85]$. Approximately $70 \%$ of the world's benzene, toluene, and xylenes supply come from petroleum naphtha, followed by pyrolysis gasoline by-product from ethylene plants at $23 \%$ and coal liquids from coke ovens at $7 \%[86]$.

The most important applications of benzene, such as: styrene, phenol, nylon, and aniline production. Toluene is typically blended into unleaded gasoline. Most toluene is produced for non-fuel consumption is used for conversion into benzene and xylenes, while the second largest end use is for solvent applications. Orthoxylene is used to produce phthalic anhydride, 
while meta-xylene is converted into isophthalic acid. Para-xylene is the most valuable xylene isomer and is converted into terephthalic acid and dimethyl terephthalate, which are ultimately used to produce polyethylene terephthalate (PET) fibers, resins, and films. The world demand for benzene, para-, ortho-, and meta-xylene was approximately $40,26,6$, and 0.4 million metric tons per year at $2005-2008$ [87].

Table 7 lists the summary of BTX production through lignin depolymerization, which reaction time is above $500{ }^{\circ} \mathrm{C}$. There are many methods to produce BTX from lignin or tar but one of the process is catalytic pyrolysis process [88]. Zeolites are effective catalysts to remove oxygen and produce desired products from biomass, resulting in increased $\mathrm{C} / \mathrm{O}$ ratio. Also significant progress has been made in the catalytic upgrading of bio-oil into fuels and chemicals [58]. Thring et al. reported the production of gasoline-range hydrocarbons from Acell lignin using H-ZSM5 as a catalyst in a fixed bed reactor, and the highest yield of liquid (43 wt\% of lignin) was obtained at $550{ }^{\circ} \mathrm{C}$ [89]. Mullen and Boateng pyrolyzed four different lignin sources over H-ZSM5 and $\mathrm{CoO} / \mathrm{MoO}_{3}$ catalysts, and found that the H-ZSM5 catalyst was the most effective for the conversion of lignin into aromatic hydrocarbons [34].

Zhao et al. studied that the selectivity to aromatic hydrocarbons was more than $87 \%$ during high temperature pyrolysis of isolated lignin after low temperature pyrolysis over a ZSM5 catalyst [90]. Jackson et al. studied fast pyrolysis of Asian lignin with five catalysts and found that HZSM-5 was the best catalyst for producing deoxygenated liquid products. However, they did not quantify the product yields [91]. Xiangyu et al. investigate the effect of HZSM- 5 catalyst. The presence of HZSM- 5 catalysts dramatically changed the product distribution. The catalytic fast pyrolysis of Kraft lignin with HZSM-5 zeolite could produce a variety of valuable chemicals, such as: BTX, ethene, and propene. The selectivity of benzene, toluene, and xylene is $15-25 \%$ for the two lignin samples [59]. Elfadly et al. studied about the effect of selectivity of BTX with ratio catalyst MCM-48, Al/MCM-48, and Zr/MCM-48. The lignin was pyrolyzed over MCM-48 support loaded with different amount of $\mathrm{Al}^{3+}$ or $\mathrm{Zr}^{4+}$ metals to produce aromatic hydrocarbon, especially BTX. The yield of BTX increased from $17.0 \%$ in case of MCM- 48 to $32.5 \%$ in case of $8.4 \%$-Al/MCM48 and $49.4 \%$ in case of $2.9 \%-\mathrm{Zr} / \mathrm{MCM}-48$ due to the enhanced acidity of the catalyst [92]. The co-hydropyrolysis of rice husk and thermo- plastic bituminous coal was carried out using a fixed-bed reactor, and promoted the higher heating value of gaseous product and the yield of BTX by $19 \%$ and $57 \%$, respectively [93]. Bi et al. [94] used HZSM-5, HY, and MCM-41 zeolite catalysts for the transformation of biomass tar to BTX aromatics selectivity of $92.9 \mathrm{C}-\mathrm{mol} \%$ with $25.1 \mathrm{wt} \%$ yield at $400{ }^{\circ} \mathrm{C}$. Che et al. [95] reported that appropriate amount (0.5 - $4 \mathrm{wt} \%)$ of loaded $\mathrm{Zn}$ species increased the strong acid site contents of the catalysts as well as BTX yields, and the highest yield (8\%) of BTX was observed under $\mathrm{Zn}$ loading amount of $2 \mathrm{wt} \%$. Up to $7 \mathrm{wt} \%$ of BTX were prepared by the catalytic pyrolysis of black liquors $(\mathrm{T}=500-600$ $\left.{ }^{\circ} \mathrm{C}\right)$ using a Ga-modified H-ZSM-5 catalyst [96].

\subsection{Terephthalic Acid Production}

Terephthalic acid (TPA) has wide utilization in the production of commonly used polyethylene terephthalate [101,102]. In the existing arts, TPA is mainly produced via the oxidation of fossil feedstocks, such as para-xylene [103]. Production of TPA from renewable biomass feedstock (e.g. lignin) has been attracting much research interest [104]. Settle et al. described TPA synthesis from biomass-derived aromatic compounds via isomerization, Diels-Alder reaction with ethylene, and dehydrogenation [105]. Bai et al. reported that a synthetic pathway for the synthesis of TPA was generated from lignin-based phenolic acids, which included hydrogenation, demethoxylation and carboxylation reactions that terephthalic acid was obtained in 58.7\% yield [106]. Song et al. reported the production of TPA from corn stover lignin [107]. They use a three-step strategy to produce terephthalic acid (TPA) from ligninderived monomer mixtures to produce cornstover-derived lignin oil with supported molybdenum catalyst. The generated 4 -alkylphenols are converted into 4alkylbenzoic acids by carbonylation with carbon monoxide. The Co-Mn$\mathrm{Br}$ catalyst oxidized various alkylchains into carboxygroups, transforming the 4-alkylbenzoic acid mixture into a single product of TPA. The overall yields of TPA based on lignin content of corn stover could reach $15.5 \mathrm{wt} \%$.

\section{Reactor Technology}

The goal of commercial catalytic process should be to convert the biomass feedstock efficiently to a high - quality liquid in high quantities such as [108]: the stabilization of the liquid product by controlling the molecular size distribution and steering the oxygen functionalities, the minimization of coke formation on 


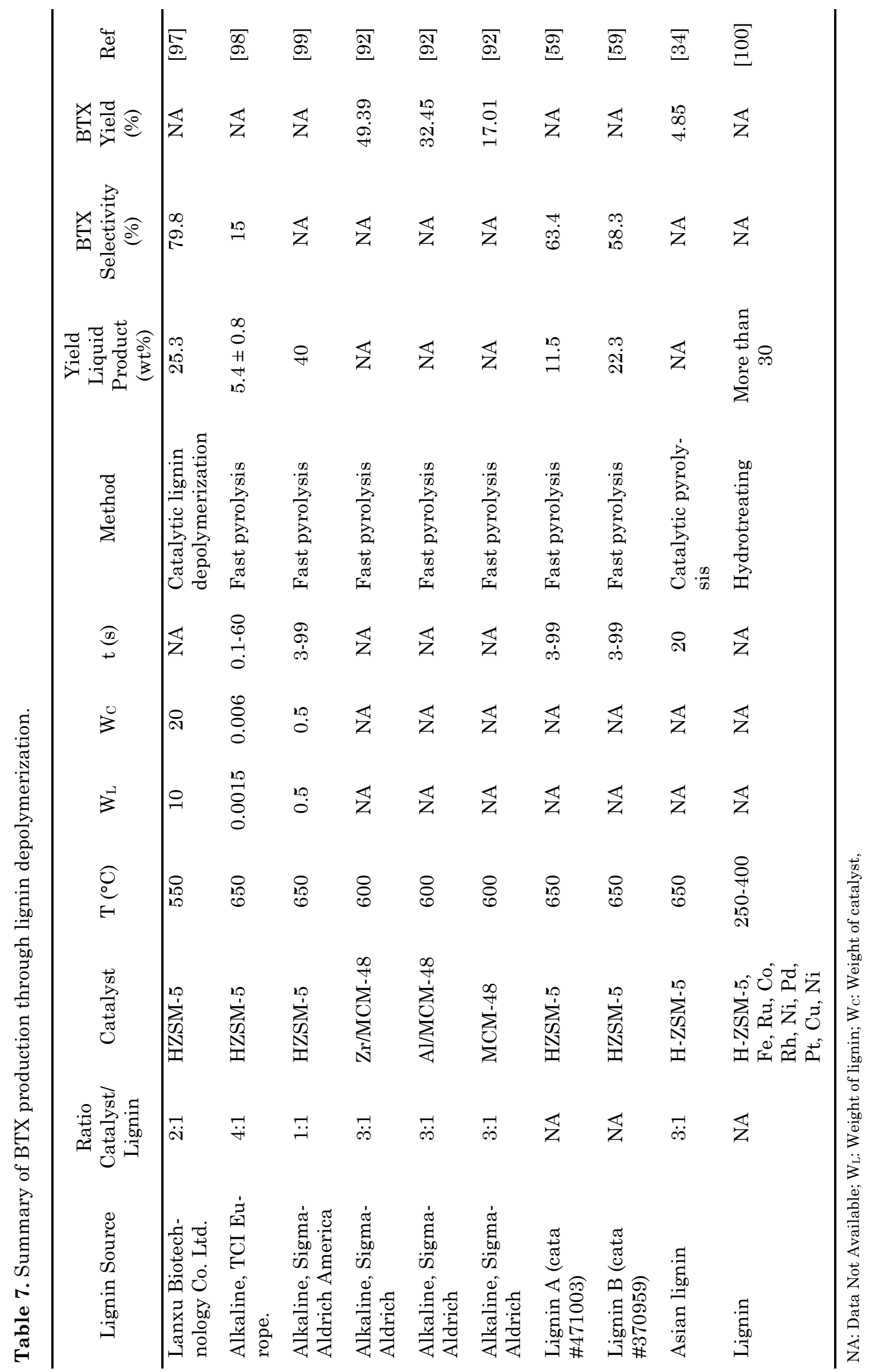


the catalyst, and the production aromatics. In order that, one need reactor technology to convert lignin to bio-oil product. A variety of reactor configurations have been investigated and reported their advantage and disadvantage [109]. Table 8 lists that reactor type with heating method including fixed-bed, fluidized-bed, rotary kiln, microwave, and centrifuge reactors in the commercial application. Two main ways of heating biomass particles in a fast pyrolysis system can be considered: gas-solid heat transfer as in an entrained flow reactor where heat is transferred from the hot gas to the pyrolysis biomass particle by primarily convection (for example the Georgia Tech Research Institute [110] or Egemin [111] processes), and solidsolid heat transfer with mostly conductive heat transfer [112].

Bridgewater reported most of the known activities in fast pyrolysis arranged by reactor type and maximum known throughput which were considerable growth and expansion of activities with more innovation in the types of reactor explored by academic institutions [113]. The reactor includes the fixed-bed, moved-bed and fluidized bed reactors. Fluidized bed has the advantages of simple in construction and operation, good temperature control and very efficient heat transfer to biomass particles arising from the high solid's density, which capacity can be reached $8000 \mathrm{~kg} / \mathrm{h}$. The microwave reactor is studied more in the recent developments in the microwave-assisted pyrolysis and solvolysis of lignin [114] (Tables 6 and 8). The microwave-assisted technology is an effective method for significantly reducing reaction time and improving the yields and selectivity of target products.

Elfadly et al. used the catalytic fast pyrolysis to produce high selectivity BTX. The pyroly-

Table 8. Pyrolysis reactors and heating methods.

\begin{tabular}{|c|c|c|c|}
\hline Reactor Type & Method of Heating & Company / Organization & Refs. \\
\hline Ablative coil & Wall heating & Castle Capital, Colorado School Mines & {$[112]$} \\
\hline Ablative mill & Wall (disc) heating & U. Aston, NREL & {$[112]$} \\
\hline Auger kiln & Wall heating & $\begin{array}{l}\text { U. Tubingen, WTC } \\
\text { Abritech, Canada Lurgi LR, Germany } \\
\text { Renewable Oil Intl, USA }\end{array}$ & {$[112,113]$} \\
\hline Circulating fluid bed & $\begin{array}{l}\text { In-bed gasification of } \\
\text { char to heat sand }\end{array}$ & U. Tubingen, WTC & [112] \\
\hline Fixed bed & $\begin{array}{l}\text { Combustion products } \\
\text { Partial gasification } \\
\text { Overfired gas }\end{array}$ & $\begin{array}{l}\text { Chemviron } \\
\text { Alten } \\
\text { Italenergie }\end{array}$ & {$[112]$} \\
\hline Fluid bed & $\begin{array}{l}\text { Heated recycle gas } \\
\text { Hot inert gas } \\
\text { Partial gasification } \\
\text { Fire tubes }\end{array}$ & $\begin{array}{l}\text { Union Fenosa } \\
\text { Agritherm, Canada } \\
\text { Biomass Engineering Ltd, UK Dyna- } \\
\text { motive, Canada } \\
\text { RTI, Canada }\end{array}$ & {$[112,113]$} \\
\hline Horizontal bed & Fire tubes & AEI, Washtech & {$[112]$} \\
\hline Multiple hearth & Hearth heating & U. Laval & {$[112]$} \\
\hline Microwave & & $\begin{array}{l}\text { Carbonscape New Zealand \& UK } \\
\text { Bioenergy } 2020 \text { b gmbh, Austria }\end{array}$ & [113] \\
\hline Rotary kiln & Wall heating & Deutsche Babcock & [112] \\
\hline Rotating cone & Wall and sand heating & U. Twente & {$[112]$} \\
\hline Stirred bed & Partial gasification & Alten & {$[112]$} \\
\hline Transported bed & Recirculated hot sand & Ensyn & [112] \\
\hline Vacuum moving bed & $\begin{array}{l}\text { Direct contact with hot } \\
\text { surface }\end{array}$ & U.Laval+Pyrovac & [112] \\
\hline $\begin{array}{l}\text { Vortex } \\
\text { Centrifuge reactor } \\
\text { Ablative }\end{array}$ & & PyTec, Germany & [113] \\
\hline
\end{tabular}


sis process was carried out using fixed-bed quartz reactor system [92]. Ma et al. had experiments using a platinum coil pyrolizer (5150, CDS Analytical). The probe was a computer controlled resistively heated element (up to $20,000{ }^{\circ} \mathrm{C} / \mathrm{s}$ ) which held an open ended quartz reactor [58]. Kouris et al. investigated the impact of scaling at equal process conditions, as well as the influence of high lignin loadings, monomer yield, solvent losses and catalyst fouling, of all which being important performance parameters for industrial operation [115]. The ratios (g/g) of yield over total feed, and yield over solvent losses are presented as qualitative indicators for capital expenditure (CAPEX) and operational expenditure (OPEX), respectively.

Until now, it is highlighted that the bio-tar was obtained from biomass or lignin but the product distribution is complicate and broad. Each product concentration is low, especially, the water content is high in the presence and absence of catalyst. Hence, if pyrolysis (even fast pyrolysis) used in this reaction system, it cannot get specific compound or high concentration product. Hence, new specific catalyst and new reaction type must be used, and then have a chance to replace petroleum oil in the future bio refineries.

For the specific compound, e.g. BTX, the candidate catalyst can be used for depolymerization is MCM-48, which is highly selectivity of BTX with ratio catalyst MCM-48, Al/MCM48, Zr/MCM-48. The yield of BTX was increased to $49.4 \%$ in case of $2.9 \%-\mathrm{Zr} / \mathrm{MCM}-48$ due to the enhanced acidity of the catalyst. The yields of TPA from corn stover lignin with supported molybdenum catalyst. could reach 15.5 wt\%.

\section{Conclusion}

Depolymerization of lignin is promising method to degrade lignin into value added products. There are so many ways to decomposition lignin, such as: base - catalyzed lignin, acid catalyzed, metallic catalyzed, pyrolysis of lignin, hydroprocessing, gasification and oxidation. The different kind of source of lignin will affect on the products distribution. Furthermore, the pyrolysis of lignin is produced water formation and it automatically from into two phases for instance water and oil content. Because of low product yield, in the future, (i) lowcost catalysts and or new reaction type (e.g. microwave-assisted reaction unit) need to be developed to achieve large-scale production of renewable fuels and value-added chemicals from lignin, and (ii) new reaction path (type) will be developed to produce the specific chemicals (e.g. BTX, PTA).

\section{Acknowledgement}

We thank for the Ministry of Science and Technology of Taiwan for financially supporting this study under the grant number MOST 107-2218-E-155-001 and the Far Eastern New Century Corporation Research \& Development Center.

\section{References}

[1] Rajesh Banu, J., Kavitha, S., Yukesh Kannah, R., Poornima Devi, T., Gunasekaran, M., Kim, S.-H., Kumar, G.A. (2019). Review on biopolymer production via lignin valorization. Bioresource Technology, 290, 121790. doi: 10.1016/j.biortech.2019.121790.

[2] Dessbesell, L., Paleologou, M., Leitch, M., Pulkki, R., Xu, C. (2020). Global lignin supply overview and kraft lignin potential as an alternative for petroleum-based polymers. Renewable and Sustainable Energy Reviews, 123, 109768. doi: 10.1016/j.rser.2020.109768.

[3] Luterbacher, J.S., Shuai, L. (2019). Production of Monomers from Lignin During Depolymerization of Lignocellulose-Containing Composition. US Patent 2019/0127304 A1.

[4] Mishra, P.K., Ekielski, A. (2019). The SelfAssembly of Lignin and Its Application in Nanoparticle Synthesis: A Short Review. Nanomaterials, $9(2), \quad 243, \quad \mathrm{doi}$ : 10.3390/nano9020243.

[5] Chio, C., Sain, M., Qin, W. (2019). Lignin utilization: A review of lignin depolymerization from various aspects. Renewable and Sustainable Energy Reviews, 107, 232-249. doi: 10.1016/j.rser.2019.03.008.

[6] Supanchaiyamat, N., Jetsrisuparb, K., Knijnenburg, J.T.N., Tsang, D.C.W., Hunt, A.J. (2019). Lignin materials for adsorption: Current trend, perspectives and opportunities. Bioresource Technology, 272, 570-581. doi: 10.1016/j.biortech.2018.09.139.

[7] Damayanti, D., Wu, H.S. (2017). Pyrolysis kinetic of alkaline and dealkaline lignin using catalyst. Journal of Polymer Research, 25, 7. doi: 10.1007/s10965-017-1401-6.

[8] Maldhure, A.V., Ekhe, J.D. (2013). Pyrolysis of purified kraft lignin in the presence of $\mathrm{AlCl}_{3}$ and $\mathrm{ZnCl}=$. Journal of Environmental Chemical Engineering, 1, 844-849. doi: 10.1016/j.jece.2013.07.026.

[9] Rößiger, B., Unkelbach, G., Pufky-Heinrich, D. (2018). Base-catalyzed depolymerization of lignin: History, challenges and perspectives. In Matheus Poletto (Ed.). Lignin-Trends and 
Applications, 99-120, InTech Publisher.

[10] Meng, Y., Lu, J., Cheng, Y., Li, Q., Wang, H. (2019). Lignin-based hydrogels: A review of preparation, properties, and application. International Journal of Biological Macromolecules, 135, $1006-1019$. doi: 10.1016/j.ijbiomac.2019.05.198.

[11] Lee, H., Jae, J., Lee, H.W., Park, S., Jeong, J., Lam, S.S., Park, Y.-K. (2020). Production of bio-oil with reduced polycyclic aromatic hydrocarbons via continuous pyrolysis of biobutanol process derived waste lignin. Journal of Hazardous Materials, 384, 121231, doi: 10.1016/j.jhazmat.2019.121231.

[12] Liu, C., Wu, S., Zhang, H., Xiao, R. (2019). Catalytic oxidation of lignin to valuable biomass-based platform chemicals: A review. Fuel Processing Technology, 191, 181-201. doi: 10.1016/j.fuproc.2019.04.007.

[13] Azadi, P., Inderwildi, O.R., Farnood, R., King, D.A. (2013). Liquid fuels, hydrogen and chemicals from lignin: A critical review. Renewable and Sustainable Energy Reviews, 21, 506-523. doi: 10.1016/j.rser.2012.12.022.

[14] Björkman, A. (1956). Studies on finely divided wood. Part 1. Extraction of lignin with neutral solvents. Svensk papperstidning, 59, 477485 .

[15] Pandey, M.P., Kim, C.S. (2011). Lignin Depolymerization and Conversion: A Review of Thermochemical Methods. Chemical Engineering \& Technology, 34, 29-41, doi: 10.1002/ceat.201000270.

[16] Abdelaziz, O.Y., Ravi, K., Mittermeier, F., Meier, S., Riisager, A., Lidén, G., Hulteberg, C.P. (2019). Oxidative Depolymerization of Kraft Lignin for Microbial Conversion. ACS Sustainable Chemistry \& Engineering, 7, 11640-11652. doi: 10.1021/acssuschemeng. $9 \mathrm{~b} 01605$.

[17] Yasuda, S., Asano, K. (2000). Preparation of strongly acidic cation-exchange resins from gymnosperm acid hydrolysis lignin. Journal of Wood Science, 46, 477-479. doi: 10.1007/bf00765807.

[18] Wang, H.-M., Wang, B., Wen, J.-L., Yuan, T.Q., Sun, R.-C. (2017). Structural Characteristics of Lignin Macromolecules from Different Eucalyptus Species. ACS Sustainable Chemistry \& Engineering, 5, 11618-11627. doi: 10.1021/acssuschemeng.7b02970.

[19] Wang, H., Tucker, M., Ji, Y. (2013). Recent Development in Chemical Depolymerization of Lignin: A Review. Journal of Applied Chemistry, 838645. doi: 10.1155/2013/838645.

[20] Zakzeski, J., Bruijnincx, P.C.A., Jongerius, A.L., Weckhuysen, B.M. (2010). The Catalytic Valorization of Lignin for the Production of
Renewable Chemicals. Chemical Reviews, 110, 3552-3599. doi: 10.1021/cr900354u.

[21] Chakar, F.S., Ragauskas, A.J. (2004). Review of current and future softwood kraft lignin process chemistry. Industrial Crops and Products, 20, 131-141. doi: 10.1016/j.indcrop.2004.04.016.

[22] Svensson, S. (2008). Minimizing the sulphur content in Kraft lignin. PhD Thesis. Mälardalen University.

[23] Malatji, P. (2009). Processing of wood and agricultural biomass for gasification. Master Thesis. University of Stellenbosch.

[24] Podgorbunskikh, E.M., Bychkov, A.L., Ryabchikova, E.I., Lomovsky, O.I. (2020). The Effect of Thermomechanical Pretreatment on the Structure and Properties of Lignin-Rich Plant Biomass. Molecules, 25(4), 995. doi: 10.3390/molecules25040995.

[25] Chen, H. (2014). Chemical Composition and Structure of Natural Lignocellulose. In Biotechnology of Lignocellulose: Theory and Practice, Springer Netherlands: Dordrecht. doi: 10.1007/978-94-007-6898-7_2, pp. 25-71.

[26] Shuhui, Y. (2001). Plant fiber chemistry; Beijing: China Light Industry Press.

[27] Tao, Y., Guan, Y. (2003). Study of chemical composition of lignin and its application. Journal of Cellulose Science and Technology, $11,42-55$.

[28] Yang, A.-L., Jiang, W.-J. (2007). Studies on a cationically modified quaternary ammonium salt of lignin. Chemical Research in Chinese Universities, 23, 479-482.

[29] Huber, G.W., Iborra, S., Corma, A. (2006). Synthesis of Transportation Fuels from Biomass: Chemistry, Catalysts, and Engineering. Chemical Reviews, 106, 4044-4098. doi: 10.1021/cr068360d.

[30] Lattner, J.R., Xu, T., Keusenkothen, P.F. (2019). Conversion of lignin to fuels and aromatics.

[31] Fernandez, A., Saffe, A., Pereyra, R., Mazza, G., Rodriguez, R. (2016). Kinetic study of regional agro-industrial wastes pyrolysis using non-isothermal TGA analysis. Applied Thermal Engineering, 106, 1157-1164. doi: 10.1016/j.applthermaleng.2016.06.084.

[32] Li, C., Zhao, X., Wang, A., Huber, G.W., Zhang, T. (2015). Catalytic Transformation of Lignin for the Production of Chemicals and Fuels. Chemical Reviews, 115, 11559-11624. doi: 10.1021/acs.chemrev.5b00155.

[33] Ponnusamy, V.K., Nguyen, D.D., Dharmaraja, J., Shobana, S., Banu, J.R., Saratale, R.G., Chang, S.W., Kumar, G. (2019). A review on lignin structure, pretreatments, fermentation 
reactions and biorefinery potential. Bioresource Technology, 271, 462-472. doi: 10.1016/j.biortech.2018.09.070.

[34] Mullen, C.A., Boateng, A.A. (2010). Catalytic pyrolysis-GC/MS of lignin from several sources. Fuel Processing Technology, 91, 14461458. doi: 10.1016/j.fuproc.2010.05.022.

[35] Nzihou, A., Stanmore, B., Lyczko, N., Minh, D.P. (2019). The catalytic effect of inherent and adsorbed metals on the fast/flash pyrolysis of biomass: A review. Energy, 170, 326337. doi: 10.1016/j.energy.2018.12.174.

[36] Roberts, V.M., Stein, V., Reiner, T., Lemonidou, A., Li, X., Lercher, J.A. (2011). Towards Quantitative Catalytic Lignin Depolymerization. Chemistry - A European Journal, 17, 5939-5948. doi: 10.1002/chem.201002438.

[37] Erdocia, X., Prado, R., Corcuera, M.Á., Labidi, J. (2014). Base catalyzed depolymerization of lignin: Influence of organosolv lignin nature. Biomass and Bioenergy, 66, 379-386. doi: 10.1016/j.biombioe.2014.03.021.

[38] Van Es, D.S., van der Klis, F., Van Haveren, J., Gosselink, R.J.A. (2014). Method for the depolymerization of lignin. European Patent, WO2014168473 (A1)

[39] Chen, J.Q., Koch, M.B. (2014). Combination of hydrogenation and base catalyzed depolymerization for lignin conversion. US Patent $8,871,989$

[40] Katahira, R., Mittal, A., McKinney, K., Chen, X., Tucker, M.P., Johnson, D.K., Beckham, G.T. (2016). Base-Catalyzed Depolymerization of Biorefinery Lignins. ACS Sustainable Chemistry \& Engineering, 4, 1474-1486. doi: 10.1021/acssuschemeng.5b01451.

[41] Hagglund, E., Bjorkman, C. (1924). Lignin hydrochloride. Biochem. Z, 147, 74-89.

[42] Binder, J.B., Gray, M.J., White, J.F., Zhang, Z.C., Holladay, J.E. (2009). Reactions of lignin model compounds in ionic liquids. Biomass and Bioenergy, 33, 1122-1130. doi: 10.1016/j.biombioe.2009.03.006.

[43] Güvenatam, B., Heeres, E.H.J., Pidko, E.A., Hensen, E.J.M. (2016). Lewis acid-catalyzed depolymerization of soda lignin in supercritical ethanol/water mixtures. Catalysis Today, 269, 9-20. doi: 10.1016/j.cattod.2015.08.039.

[44] Güvenatam, B., Heeres, E.H.J., Pidko, E.A., Hensen, E.J.M. (2016). Lewis-acid catalyzed depolymerization of Protobind lignin in supercritical water and ethanol. Catalysis Today, $259, \quad 460-466 . \quad$ d o i : 10.1016/j.cattod.2015.03.041.

[45] Deepa, A.K., Dhepe, P.L. (2014). Solid acid catalyzed depolymerization of lignin into value added aromatic monomers. RSC Advances, 4, 12625-12629. doi: 10.1039/C3RA47818A.
[46] Yang, L., Li, Y., Savage, P.E. (2014). Hydrolytic Cleavage of $\mathrm{C}-\mathrm{O}$ Linkages in Lignin Model Compounds Catalyzed by WaterTolerant Lewis Acids. Industrial \& Engineering Chemistry Research, 53, 2633-2639. doi: 10.1021/ie403545n.

[47] Gasson, J.R., Forchheim, D., Sutter, T., Hornung, U., Kruse, A., Barth, T. (2012). Modeling the Lignin Degradation Kinetics in an Ethanol/Formic Acid Solvolysis Approach. Part 1. Kinetic Model Development. Industrial \& Engineering Chemistry Research, 51, 10595-10606. doi: 10.1021/ie301487v.

[48] Elliott, D.C.T. (1983). Hydrodeoxygenation of phenolic components of wood-derived oil. In Proceedings of Am. Chem. Soc. Div. Pet. Chem., p. 667.

[49] Ben, H., Ragauskas, A.J. (2011). Pyrolysis of Kraft Lignin with Additives. Energy \& Fuels, 25, 4662-4668. doi: 10.1021/ef2007613.

[50] Brebu, M., Cazacu, G., Chirila, O. (2011). Pyrolysis of lignin - a potential method for obtaining chemcials and/or fuels. Celluose Chemistry and Technology, 45, 43-50.

[51] Meier, D., Faix, O. (1999). State of the art of applied fast pyrolysis of lignocellulosic materials - a review. Bioresource Technology, 68, 71-77. doi: 10.1016/S0960-8524(98)00086-8.

[52] Mohan, D., Pittman, C.U., Steele, P.H. (2006). Pyrolysis of Wood/Biomass for Bio-oil: A Critical Review. Energy \& Fuels, 20, 848889. doi: 10.1021/ef0502397.

[53] Uçar, S., Karagöz, S. (2009). The slow pyrolysis of pomegranate seeds: The effect of temperature on the product yields and bio-oil properties. Journal of Analytical and Applied Pyrolysis, 84, 151-156. doi: 10.1016/j.jaap.2009.01.005.

[54] Yaman, S. (2004). Pyrolysis of biomass to produce fuels and chemical feedstocks. Energy Conversion and Management, 45, 651-671. doi: 10.1016/S0196-8904(03)00177-8.

[55] Charon, N., Ponthus, J., Espinat, D., Broust, F., Volle, G., Valette, J., Meier, D. (2015). Multi-technique characterization of fast pyrolysis oils. Journal of Analytical and Applied Pyrolysis, $116, \quad 18-26$. doi : 10.1016/j.jaap.2015.10.012.

[56] Lei, M., Wu, S., Liang, J., Liu, C. (2019). Comprehensive understanding the chemical structure evolution and crucial intermediate radical in situ observation in enzymatic hydrolysis/mild acidolysis lignin pyrolysis. Journal of Analytical and Applied Pyrolysis, 138, 249-260. doi: 10.1016/j.jaap.2019.01.004.

[57] Cho, J., Chu, S., Dauenhauer, P.J., Huber, G.W. (2012). Kinetics and reaction chemistry for slow pyrolysis of enzymatic hydrolysis lig- 
nin and organosolv extracted lignin derived from maplewood. Green Chemistry, 14, 428439.

[58] Ma, Z., Troussard, E., van Bokhoven, J.A. (2012). Controlling the selectivity to chemicals from lignin via catalytic fast pyrolysis. Applied Catalysis A: General, 423-424, 130136. doi: 10.1016/j.apcata.2012.02.027.

[59] Li, X., Su, L., Wang, Y., Yu, Y., Wang, C., Li, X., Wang, Z. (2012). Catalytic fast pyrolysis of Kraft lignin with HZSM-5 zeolite for producing aromatic hydrocarbons. Frontiers of Environmental Science \& Engineering, 6, 295-303. doi: 10.1007/s11783-012-0410-2.

[60] Fu, D., Farag, S., Chaouki, J., Jessop, P.G. (2014). Extraction of phenols from lignin microwave-pyrolysis oil using a switchable hydrophilicity solvent. Bioresource Technology, $\begin{array}{lllllllllll}1 & 5 & 4 & 1 & 0 & 1 & - & 1 & 0 & 8 & \end{array} \quad$ d o i : 10.1016/j.biortech.2013.11.091.

[61] Nowakowski, D.J., Bridgwater, A.V., Elliott, D.C., Meier, D., de Wild, P. (2010). Lignin fast pyrolysis: Results from an international collaboration. Journal of Analytical and Applied Pyrolysis, 88, $53-72$. doi : 10.1016/j.jaap.2010.02.009.

[62] Garcìa-Pérez, M., Chaala, A., Pakdel, H., Kretschmer, D., Roy, C. (2007). Vacuum pyrolysis of softwood and hardwood biomass: Comparison between product yields and biooil properties. Journal of Analytical and Applied Pyrolysis, 78, 104-116. doi: 10.1016/j.jaap.2006.05.003.

[63] Farag, S., Fu, D., Jessop, P.G., Chaouki, J. (2014). Detailed compositional analysis and structural investigation of a bio-oil from microwave pyrolysis of kraft lignin. Journal of Analytical and Applied Pyrolysis, 109, 249257. doi: 10.1016/j.jaap.2014.06.005.

[64] Choi, Y.S., Johnston, P.A., Brown, R.C., Shanks, B.H., Lee, K.-H. (2014). Detailed characterization of red oak-derived pyrolysis oil: Integrated use of GC, HPLC, IC, GPC and Karl-Fischer. Journal of Analytical and Applied Pyrolysis, 110, 147-154. doi: 10.1016/j.jaap.2014.08.016.

[65] Matos, M., Mattos, B.D., de Cademartori, P.H., Lourençon, T.V., Hansel, F.A., Zanoni, P.R., Yamamoto, C.I., Magalhães, W.L. (2020). Pilot-Scaled Fast-Pyrolysis Conversion of Eucalyptus Wood Fines into Products: Discussion Toward Possible Applications in Biofuels, Materials, and Precursors. BioEnergy Research, 13, 411-422, doi: 10.1007/s12155020-10094-y .

[66] Tanoh, T.S., Ait Oumeziane, A., Lemonon, J., Escudero Sanz, F.J., Salvador, S. (2020). Green waste/ wood pellets pyrolysis in a pilotscale rotary kiln: effect of temperature on product distribution and characteristics. Energy \& Fuels, 34, 3336-3345. doi: 10.1021/acs.energyfuels.9b04365.

[67] Wang, Z., He, T., Qin, J., Wu, J., Li, J., Zi, Z., Liu, G., Wu, J., Sun, L. (2015). Gasification of biomass with oxygen-enriched air in a pilot scale two-stage gasifier. Fuel, 150, 386-393. doi: 10.1016/j.fuel.2015.02.056.

[68] Zhang, Q., Chang, J., Wang, T., Xu, Y. (2007). Review of biomass pyrolysis oil properties and upgrading research. Energy Conversion and Management, 48, 87-92. doi: 10.1016/j.enconman.2006.05.010.

[69] Diebold, J.P. (1999). A review of the chemical and physical mechanisms of the storage stability of fast pyrolysis bio-oils; National Renewable Energy Lab., Golden, CO (US).

[70] Collard, F.-X., Blin, J. (2014). A review on pyrolysis of biomass constituents: Mechanisms and composition of the products obtained from the conversion of cellulose, hemicelluloses and lignin. Renewable and Sustainable Energy Reviews, 38, 594-608. doi: 10.1016/j.rser.2014.06.013.

[71] Duman, G., Okutucu, C., Ucar, S., Stahl, R., Yanik, J. (2011). The slow and fast pyrolysis of cherry seed. Bioresource Technology, 102, $\begin{array}{lllllllllllllll}1 & 8 & 6 & 9 & - & 1 & 8 & 7 & 8 & & & & d & o & i\end{array}:$ 10.1016/j.biortech.2010.07.051.

[72] Vitasari, C.R., Meindersma, G.W., de Haan, A.B. (2011). Water extraction of pyrolysis oil: The first step for the recovery of renewable chemicals. Bioresource Technology, 102, 72047210. doi: 10.1016/j.biortech.2011.04.079.

[73] Heeres, A., Schenk, N., Muizebelt, I., Blees, R., de Waele, B., Zeeuw, A.J., Meyer, N., Carr, R., Wilbers, E., Heeres, H.J. (2018). Synthesis of bio-aromatics from black liquors using catalytic pyrolysis. ACS Sustainable Chemistry \& Engineering, 6(3), 3472-3480. doi: 10.1021/acssuschemeng.7b03728.

[74] Gómez, N., Banks, S.W., Nowakowski, D.J., Rosas, J.G., Cara, J., Sánchez, M.E., Bridgwater, A.V. (2018). Effect of temperature on product performance of a high ash biomass during fast pyrolysis and its bio-oil storage evaluation. Fuel Processing Technology, 172, 97-105. doi: 10.1016/j.fuproc.2017.11.021.

[75] Cen, K., Zhang, J., Ma, Z., Chen, D., Zhou, J., $\mathrm{Ma}, \mathrm{H}$. (2019). Investigation of the relevance between biomass pyrolysis polygeneration and washing pretreatment under different severities: Water, dilute acid solution and aqueous phase bio-oil. Bioresource Technology, $278, \quad 26-33 . \quad$ d o i : 10.1016/j.biortech.2019.01.048.

[76] Chen, W., Chen, Y., Yang, H., Li, K., Chen, X., Chen, H. (2018). Investigation on biomass nitrogen-enriched pyrolysis: Influence of tem- 
perature. Bioresource Technology, 249, 247253. doi: 10.1016/j.biortech.2017.10.022.

[77] Mäki-Arvela, P., Murzin, D. (2017). Hydrodeoxygenation of Lignin-Derived Phenols: From Fundamental Studies towards Industrial Applications. Catalysts, 7(9), 265, doi: 10.3390/catal7090265

[78] Shimanskaya, E., Stepacheva, A.A., Sulman, E., Rebrov, E., Matveeva, V. (2018). Lignincontaining feedstock hydrogenolysis for biofuel component production. Bulletin of Chemical Reaction Engineering \& Catalysis, 13, 74-81.

[79] Demirbaş, A. (2002). Gaseous products from biomass by pyrolysis and gasification: effects of catalyst on hydrogen yield. Energy Conversion and Management, 43, 897-909. doi: 10.1016/S0196-8904(01)00080-2.

[80] Reddy, S.N., Nanda, S., Dalai, A.K., Kozinski, J.A. (2014). Supercritical water gasification of biomass for hydrogen production. International Journal of Hydrogen Energy, 39, 69126926. doi: 10.1016/j.ijhydene.2014.02.125.

[81] Islam, M.W. (2020). A review of dolomite catalyst for biomass gasification tar removal. Fuel, $\quad 267, \quad 117095$. d o i : 10.1016/j.fuel.2020.117095.

[82] Macrì, D., Catizzone, E., Molino, A., Migliori, M. (2020). Supercritical water gasification of biomass and agro-food residues: Energy assessment from modelling approach. Renewable Energy, 150, 624-636. doi: 10.1016/j.renene.2019.12.147.

[83] Cao, C., Bian, C., Wang, G., Bai, B., Xie, Y., Jin, H. (2020). Co-gasification of plastic wastes and soda lignin in supercritical water. Chemical Engineering Journal, 388, 124277. doi: 10.1016/j.cej.2020.124277.

[84] Kirk, R., Othmer, D. (1992). Encyclopedia of Chemical Technology John Wiley \& Sons: Vol. 4.

[85] Singh, S. (2019). Biodegradation of waste streams containing benzene, toluene, ethylbenzene and xylene (BTEX): Practical implications and brief perspectives. Annals of Advances in Chemistry, 3, 007-010. doi: 10.29328/journal.aac.1001018.

[86] Meyers, R.A. (2004). Handbook of Petroleum Refining Processes 3rd ed.; McGraw-Hill Education: New York.

[87] Niziolek, A.M., Onel, O., Floudas, C.A. (2016). Production of benzene, toluene, and xylenes from natural gas via methanol: Process synthesis and global optimization. AIChE Journal, 62, 1531-1556, doi: 10.1002/aic.15144.

[88] Kostyniuk, A., Grilc, M., Likozar, B. (2019). Catalytic Cracking of Biomass-Derived Hydrocarbon Tars or Model Compounds to Form
Biobased Benzene, Toluene, and Xylene Isomer Mixtures. Industrial \& Engineering Chemistry Research, 58, 7690-7705. doi: 10.1021/acs.iecr.9b01219.

[89] Thring, R.W., Katikaneni, S.P.R., Bakhshi, N.N. (2000). The production of gasoline range hydrocarbons from Alcell® lignin using HZSM-5 catalyst. Fuel Processing Technology, 62, 17-30, doi: 10.1016/S03783820(99)00061-2.

[90] Ma, Z., Troussard, E., van Bokhoven, J.A. (2012). Controlling the selectivity to chemicals from lignin via catalytic fast pyrolysis. Applied Catalysis A: General, 423-424, 130136. doi: 10.1016/j.apcata.2012.02.027.

[91] Jackson, M.A., Compton, D.L., Boateng, A.A. (2009). Screening heterogeneous catalysts for the pyrolysis of lignin. Journal of Analytical and Applied Pyrolysis, 85, 226-230. doi: 10.1016/j.jaap.2008.09.016.

[92] Elfadly, A.M., Zeid, I.F., Yehia, F.Z., Rabie, A.M., aboualala, M.M., Park, S.-E. (2016). Highly selective BTX from catalytic fast pyrolysis of lignin over supported mesoporous silica. International Journal of Biological Macromolecules, 91, 278-293. doi: 10.1016/j.ijbiomac.2016.05.053.

[93] Zhang, J., Zheng, N., Wang, J. (2018). Comparative investigation of rice husk, thermoplastic bituminous coal and their blends in production of value-added gaseous and liquid products during hydropyrolysis/cohydropyrolysis. Bioresource Technology, 268, 445-453. doi: 10.1016/j.biortech.2018.08.018.

[94] Bi, P., Yuan, Y., Fan, M., Jiang, P., Zhai, Q., Li, Q. (2013). Production of aromatics through current-enhanced catalytic conversion of bio-oil tar. Bioresource Technology, $136, \quad 222-229 . \quad \mathrm{d}$ o i : 10.1016/j.biortech.2013.02.100.

[95] Che, Q., Yang, M., Wang, X., Yang, Q., Rose Williams, L., Yang, H., Zou, J., Zeng, K., Zhu, Y., Chen, Y., Chen, H. (2019). Influence of physicochemical properties of metal modified ZSM-5 catalyst on benzene, toluene and xylene production from biomass catalytic pyrolysis. Bioresource Technology, 278, 248-254. doi: 10.1016/j.biortech.2019.01.081.

[96] Heeres, A., Schenk, N., Muizebelt, I., Blees, R., De Waele, B., Zeeuw, A.-J., Meyer, N., Carr, R., Wilbers, E., Heeres, H.J. (2018). Synthesis of Bio-aromatics from Black Liquors Using Catalytic Pyrolysis. ACS Sustainable Chemistry \& Engineering, 6, 3472-3480. doi: 10.1021/acssuschemeng.7b03728.

[97] Fan, M.-H., Deng, S.-M., Wang, T.-J., Li, Q.X. (2014). Production of BTX through catalytic depolymerization of lignin. Chinese Journal of Chemical Physics, 27, 221-226. 
[98] Ma, Z., Custodis, V., van Bokhoven, J.A. (2014). Selective deoxygenation of lignin during catalytic fast pyrolysis. Catalysis Science \& Technology, 4, 766-772.

[99] Deepa, A.K., Dhepe, P.L. (2015). Lignin Depolymerization into Aromatic Monomers over Solid Acid Catalysts. ACS Catalysis, 5, 365379. doi: 10.1021/cs501371q.

[100] Kellett, P.J., Collias, D.I. (2016). Catalysts and processes for the production of aromatic compounds from lignin. US Patent 9452422 B2.

[101] Fakirov, S. (2002). Handbook of thermoplastic polyesters; Wiley-Vch: Vol. 2.

[102] Scheirs, J., Long, T.E. (2005). Modern polyesters: chemistry and technology of polyesters and copolyesters; John Wiley \& Sons.

[103] Fadzil, N.A.M., Rahim, M.H.A., Maniam, G.P. (2014). A brief review of para-xylene oxidation to terephthalic acid as a model of primary C$\mathrm{H}$ bond activation. Chinese Journal of Catalysis, 35, 1641-1652. doi: 10.1016/S18722067(14)60193-5.

[104] Wendisch, V.F., Kim, Y., Lee, J.-H. (2018). Chemicals from lignin: Recent depolymerization techniques and upgrading extended pathways. Current Opinion in Green and Sustainable Chemistry, 14, 33-39. doi: 10.1016/j.cogsc.2018.05.006.

[105] Settle, A.E., Berstis, L., Rorrer, N.A., RomanLeshkóv, Y., Beckham, G.T., Richards, R.M., Vardon, D.R. (2017). Heterogeneous DielsAlder catalysis for biomass-derived aromatic compounds. Green Chemistry, 19, 3468-3492. doi: 10.1039/c7gc00992e.

[106] Bai, Z., Phuan, W.C., Ding, J., Heng, T.H., Luo, J., Zhu, Y. (2016). Production of Terephthalic Acid from Lignin-Based Phenolic Acids by a Cascade Fixed-Bed Process. ACS Catalysis, 6, 6141-6145. doi: 10.1021/acscatal. $6 \mathrm{~b} 02052$.

[107] Song, S., Zhang, J., Gözaydın, G., Yan, N. (2019). Production of Terephthalic Acid from Corn Stover Lignin. Angewandte Chemie, 131, 4988-4991. doi: 10.1002/ange.201814284.
[108] Yildiz, G., Ronsse, F., Duren, R.v., Prins, W. (2016). Challenges in the design and operation of processes for catalytic fast pyrolysis of woody biomass. Renewable and Sustainable Energy Reviews, 57, 1596-1610. doi: 10.1016/j.rser.2015.12.202.

[109] Parihar, A., Bhattacharya, S. (2019). Cellulose fast pyrolysis for platform chemicals: assessment of potential targets and suitable reactor technology. Biofuels, Bioproducts and Biorefining, $14(2), \quad 446-468$. doi: 10.1002/bbb.2066.

[110] Kovac, R., O'Neil, D. (1989). The Georgia Tech entrained flow pyrolysis process. In $P y$ rolysis and gasification, Ferrero, G.L., Maniatis, K., Buekens, A., Bridgwater, A.V., Eds. Elsevier Applied Science: pp. 169-179.

[111] Maniatis, K., Baeyens, J., Peeters, H., Roggeman, G. (1993). The Egemin flash pyrolysis process: commissioning and initial results. In Advances in thermochemical biomass conversion, Bridgwater, A.V., Boocock, D.G.G., Eds. Springer: pp. 1257-1264.

[112] Bridgwater, A.V. (1999). Principles and practice of biomass fast pyrolysis processes for liquids. Journal of Analytical and Applied Pyrolysis, 51, 3-22. doi: 10.1016/S01652370(99)00005-4.

[113] Bridgwater, A.V. (2012). Review of fast pyrolysis of biomass and product upgrading. Biomass and Bioenergy, 38, 68-94. doi: 10.1016/j.biombioe.2011.01.048.

[114] Yunpu, W., Leilei, D.A.I., Liangliang, F.A.N., Shaoqi, S., Yuhuan, L.I.U., Roger, R. (2016). Review of microwave-assisted lignin conversion for renewable fuels and chemicals. Journal of Analytical and Applied Pyrolysis, 119, 104-113. doi: 10.1016/j.jaap.2016.03.011.

[115] Kouris, P.D., Huang, X., Boot, M.D., Hensen, E.J.M. (2018). Scaling-Up Catalytic Depolymerisation of Lignin: Performance Criteria for Industrial Operation. Topics in Catalysis, 61, 1901-1911. doi: 10.1007/s11244-018-10485. 